NBER WORKING PAPER SERIES

\title{
PRIVATE EQUITY'S UNINTENDED DARK SIDE: ON THE ECONOMIC CONSEQUENCES OF EXCESSIVE DELISTINGS
}

\author{
Alexander Ljungqvist \\ Lars Persson \\ Joacim Tåg \\ Working Paper 21909 \\ http://www.nber.org/papers/w21909 \\ NATIONAL BUREAU OF ECONOMIC RESEARCH \\ 1050 Massachusetts Avenue \\ Cambridge, MA 02138 \\ January 2016
}

Financial support from the Swedish Securities Dealers Association Support Foundation (Persson and Tåg) and from the Marianne and Marcus Wallenberg Foundation (Ljungqvist) is gratefully acknowledged. We thank Brent Goldfarb, Armando Gomes, Josh Lerner, Gustavo Manso, Morten Sørensen, Thomas Tangerås, Sheridan Titman, and audiences at the Helsinki Center for Economic Research, Lund University, the 2014 Distinguished Public Lecture at the Institute for Advanced Study, the 2015 Dean's Lecture at City University, the 2015 IFN Workshop on Corporate Ownership, the 2016 Henry Grunfeld Lecture, and the 2016 LBS Private Equity Symposium for excellent comments and suggestions. Fredrik Andersson, Charlotta Olofsson, Arvid Hedlund, Malin Olsson Tallås, and Olga Pugatšova provided outstanding research assistance. Ljungqvist gratefully acknowledges the generous hospitality of IFN while working on this project. The views expressed herein are those of the authors and do not necessarily reflect the views of the National Bureau of Economic Research.

NBER working papers are circulated for discussion and comment purposes. They have not been peer-reviewed or been subject to the review by the NBER Board of Directors that accompanies official NBER publications.

(C) 2016 by Alexander Ljungqvist, Lars Persson, and Joacim Tåg. All rights reserved. Short sections of text, not to exceed two paragraphs, may be quoted without explicit permission provided that full credit, including $(\odot$ notice, is given to the source. 
Private Equity's Unintended Dark Side: On the Economic Consequences of Excessive Delistings Alexander Ljungqvist, Lars Persson, and Joacim Tåg

NBER Working Paper No. 21909

January 2016, Revised December 2016

JEL No. G24,G34,P16

\begin{abstract}
Over the past two decades, the U.S. stock market has been shrinking as the public firm model has begun to fall out of favor. We develop a political economy model of delistings to study the wider economic consequences of this trend. We show that the private and social incentives to delist firms from the stock market need not be aligned. Delistings can inadvertently impose an externality on the economy by reducing citizen-investors' exposure to corporate profits and thereby undermining popular support for business-friendly policies. By facilitating companies' departures from the stock market, private equity firms can trigger a chain of events that may lead to long-term reductions in aggregate investment, productivity, and employment.
\end{abstract}

Alexander Ljungqvist

Stern School of Business

New York University

44 West Fourth Street, \#9-160

New York, NY 10012

and NBER

aljungqv@stern.nyu.edu

Lars Persson

Research Institute of Industrial Economics

lars.persson@ifn.se
Joacim Tåg

Research Institute of Industrial Economics

joacim.tag@ifn.se 


\section{Introduction}

The number of firms listed on the U.S. stock market has fallen dramatically in recent years. Using data going back to 1946, Figure 1 shows that the number of listed firms peaked at 7,428 in 1997 and has since declined almost monotonically. By December 2015, it stands at 3,754-half the 1997 count. Doidge, Karolyi, and Stulz (2016) attribute $46 \%$ of this decline to a historically high number of delistings (the remainder being due to an unusually low level of IPO activity). We estimate that since the turn of the century, an average of 407 firms (or $8.3 \%$ of the annual total) have delisted every year. ${ }^{1}$ Delistings have outnumbered IPOs in every year since the number of U.S. listed firms peaked in 1997, except in 2014. Companies delist for a variety of reasons - they go bankrupt, are delisted by an exchange for violating listing standards, or are acquired—but in recent years, as Doidge, Karolyi, and Stulz note,"[t]he high delist rate is explained by an unusually high rate of acquisitions of publicly-listed firms compared to previous U.S. history.”

Figure 1: The number of listed U.S. companies, 1946-2015.

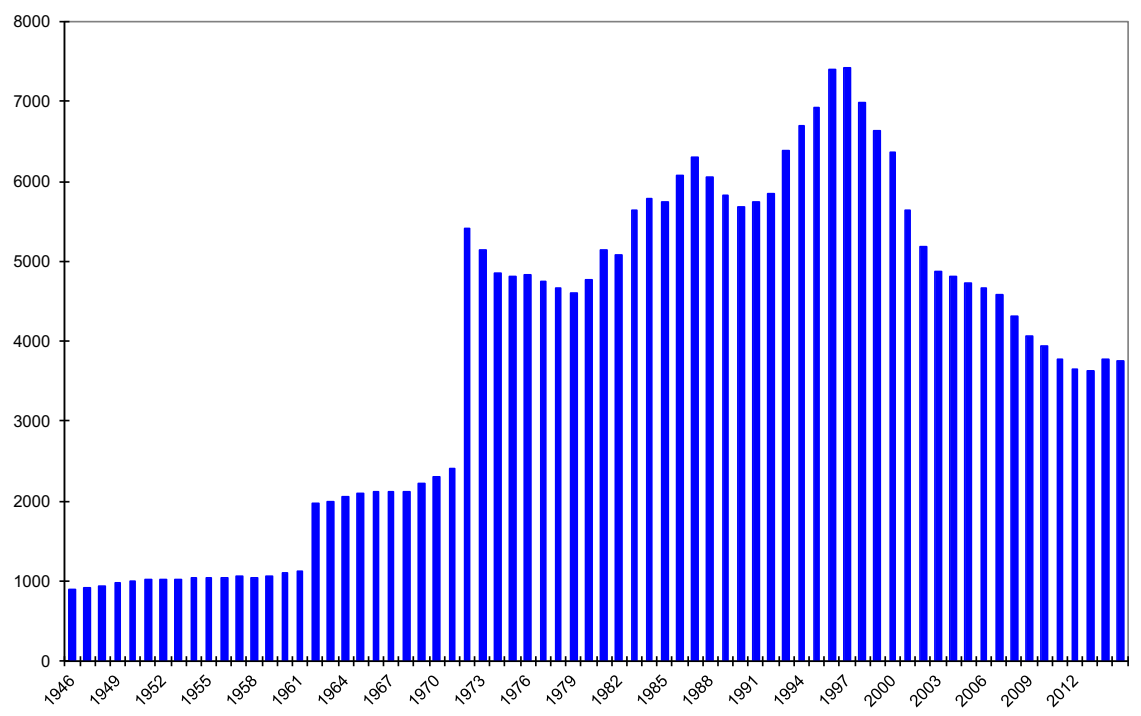

Notes. The number of listed companies is extracted from the monthly CRSP files. We count the number of U.S. companies listed on the NYSE, American Stock Exchange, and Nasdaq each December. To ensure that we capture only U.S. listed operating companies, we restrict the analysis to CRSP share codes 10 and 11. The sharp increase in 1962 is an artifact of the CRSP files: CRSP has no data for the American Stock Exchange before 1962. The jump in 1971 reflects the creation of the Nasdaq stock exchange.

In this paper, we explore whether the shrinking of the stock market, were it to continue unchecked, could impose a major externality on the economy, by undermining what economic historians have termed

\footnotetext{
${ }^{1}$ The estimate is based on CRSP data comparing the annual number of delistings of U.S. companies from the NYSE, American Stock Exchange, and Nasdaq to the total number of U.S. companies listed on these exchanges in December of the previous year.
} 
the hard-won "consensus" in support of shareholder capitalism that has emerged in Anglo-Saxon economies over the past 100 years: in return for participating in the gains from corporate activity, shareholder-voters lend their support to business-friendly policies. ${ }^{2}$

To study the potential economic consequences of a shrinking stock market, we develop a political economy model of delistings that incorporates publicly listed and privately held firms, citizen-workers and citizen-investors who vote for parties based on their political preferences, political parties that determine the business climate in the economy, and corporate investment. We frame our analysis in terms of a private equity (PE) firm's decision to buy out firms from the stock market. Unlike acquisitions by strategic buyers that are themselves listed, buyout transactions involving PE firms shrink the stock market, at least for a number of years. ${ }^{3}$ Fueled by cheap debt ${ }^{4}$ and the perception that the costs of being listed have begun to outweigh the benefits, ${ }^{5}$ PE firms account for a sizeable share of delisting activity in the U.S. Figure 2 shows that PE buyout activity reached a peak in 2006, when it accounted for $23.3 \%$ of delistings by number and $47.9 \%$ by value, equivalent to $1.9 \%$ of stock market capitalization and $2 \%$ of GDP that year. Since 2000, PE firms have been involved in $9.2 \%$ of all U.S. delistings by number and $14.6 \%$ by value, taking companies worth a combined 6\% of GDP private. According to figures published in The Economist, one in four mid-sized firms and one in ten large firms in the U.S. are under PE ownership as of 2016, with one PE firm (Carlyle) employing 725,000 people, second only to Walmart. ${ }^{6}$

Our political economy model shows that the private incentives to delist companies from the stock market need not coincide with the social incentives to do so. In other words, the rate of delistings can become excessive. This can happen because shareholders in public companies do not internalize that when they agree to sell out, their political preferences may change in a way detrimental to the interests of the shareholders of other companies. Put differently, even though sellers understand that their behavior can lead to adverse

\footnotetext{
${ }^{2}$ Milestones on the path to this "consensus" include the World War I Liberty Bond program, the 1920s "New Proprietorship" movement aimed at shaping political preferences through employee and customer ownership plans in the U.S., Thatcher-era policies to create a "shareholder democracy" in the U.K. through the sale of state assets, and George W. Bush's mid-2000s attempts to promote an "ownership society." See Ott $(2004,2007,2008)$ for a comprehensive historical analysis.

${ }^{3}$ Kaplan and Strömberg (2009) report that once delisted, only 14\% of buyout targets are eventually relisted on the stock market. A further $38 \%$ are sold to strategic buyers, some of which are themselves listed. The remaining half of PE buyout targets leave the stock market permanently.

${ }^{4} \mathrm{PE}$ activity varies systematically with conditions in the debt markets (Axelson, Strömberg, and Weisbach 2009, Axelson et al. 2013).

${ }^{5}$ See, for example, The Economist's recent leader titled "Float like a butterfly" and the special briefing titled "Private equity: The Barbarian establishment" (both Oct. 22, 2016), arguing that "managers grumble that being in the public eye has become a gigantic headache. Listed firms face ever more red tape. Then there is the treadmill of quarterly results, with the ever-present risk that Wall Street will punish even short-term slip-ups."

${ }^{6}$ See "Float like a butterfly" (Oct. 22, 2016).
} 
Figure 2: The share of public-to-private buyouts in delistings, 1977-2014.

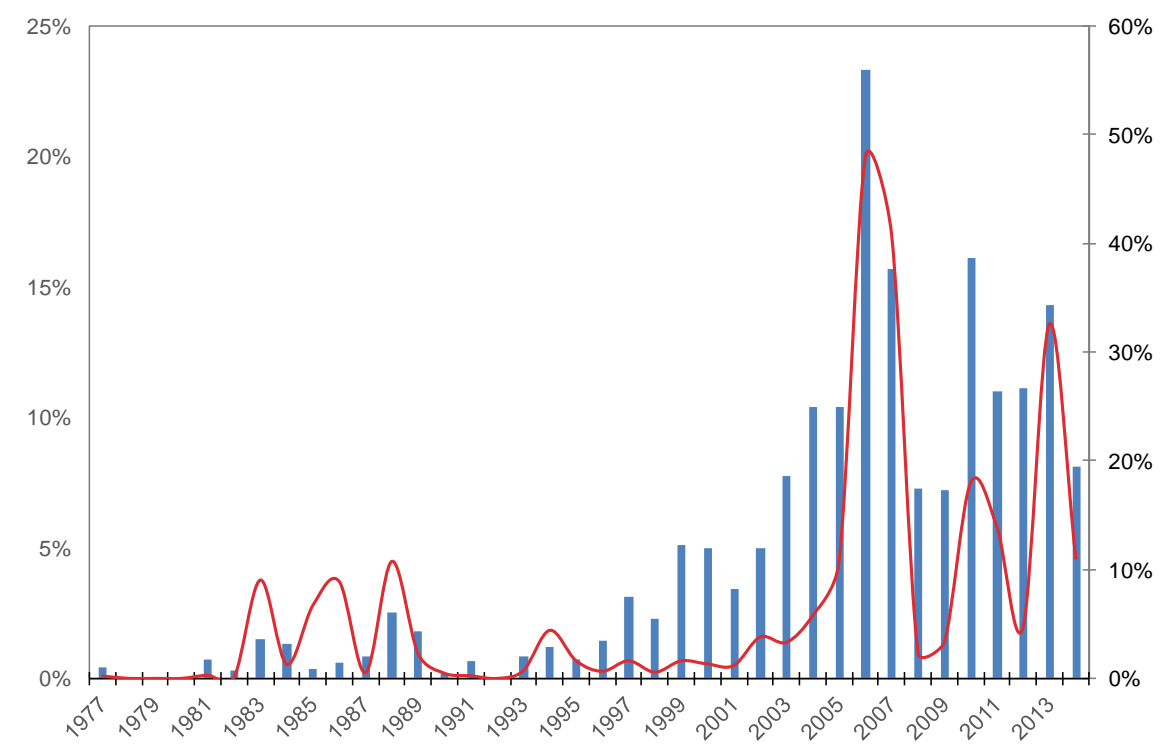

Notes. The figure shows the share of public-to-private delistings in U.S. delistings by number (bars, left axis) and by value (solid line, right axis). The numerator (the annual number or value of public-to-private delistings) is constructed using data taken from CapitalIQ, screening for leveraged buyouts or management buyouts flagged as going-private transactions and involving the acquisition of a majority stake in a U.S.-headquartered target. The denominator (the annual number or value of delistings) is based on CRSP data for delistings of U.S. companies from the NYSE, American Stock Exchange, and Nasdaq, using the number of shares outstanding and the share price in the month before delisting to estimate market values.

long-term consequences for the economy, it is privately optimal for them to sell at the price at which the PE firm offers to buy them out.

The mechanism at the heart of our model is that delistings reduce the size of the stock market and stock market participation and hence the extent to which citizens have an economic reason to care about the government fostering a business-friendly climate. Figure 3 provides suggestive evidence of a possible link between the size of the stock market and a measure of stock market participation derived from tax returns. After rising from below $10 \%$ of taxpayers at the end of World War II to a high of $26.4 \%$ in 2000 , stock market participation has fallen to $18.6 \%$ in 2014 (the latest year for which data are available). ${ }^{7}$ U.S. stock market participation thus seems to track the number of listed companies fairly closely. Indeed, the contemporaneous correlation is $80.9 \%$ over this time frame.

An example of a business-friendly policy is trade liberalization. Gallup has tracked attitudes to free

\footnotetext{
${ }^{7}$ Our measure of stock market participation is based on the number of taxpayers who report taxable dividend income on their tax returns. Taxpayers who purchase exclusively non-dividend-paying stocks are thus not included in the measure. While data on individual investors' portfolios are not available in the U.S., it is worth noting that the decline in our measure of stock market participation after 2000 does not coincide with a systematic decline in the fraction of firms paying dividends. See Floyd, Li, and Skinner (2015).
} 
Figure 3: The number of listed firms and stock market participation, 1946-2015.

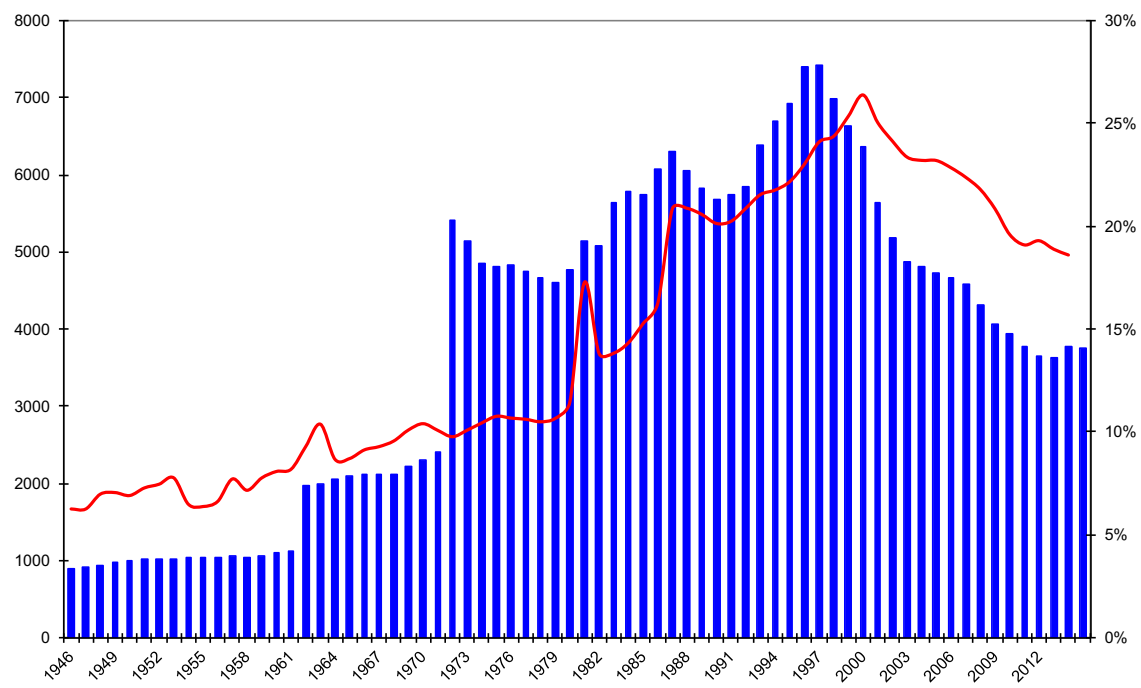

Notes. Stock market participation is proxied using the fraction of all federal tax returns in the U.S. that report taxable dividend income. Dividend income includes distributions from mutual funds but excludes non-taxable dividends such as those received in 401(k) pension plans. Tax return data are obtained from the IRS website.

trade among U.S. voters since 1992, when the North American Free Trade Area was being negotiated. ${ }^{8}$ The correlation between the share of respondents who view free trade as a threat (rather than as an opportunity) and the number of stock market listed firms in the U.S. is $-43.1 \%$; the correlation with the annual value of delistings involving PE firms is 29.6\%; and the correlation with our measure of stock market participation is $-36.6 \%$. In other words, as the stock market has shrunk in the wake of large-scale buying by PE firms, and stock market participation has declined, voter attitudes have turned against free trade. These correlations are consistent with (but of course not causal proof of) a link between voters' exposure to corporate profits via the stock market and their attitudes to business-friendly policies.

Formally, we model an economy with three classes of citizens (workers, the middle class, and entrepreneurs), two types of firms (stock market listed firms owned by the middle class and privately held firms owned by entrepreneurs), a PE firm, and two political parties (a left-wing party catering to workers and a right-wing party catering to entrepreneurs). ${ }^{9}$ The game proceeds in four stages. First, the PE firm bids to take some public firms private. Second, citizens maximize their utility of consumption by voting for the party that maximizes their income from employment and from capital (if any). Third, the party that wins the

\footnotetext{
${ }^{8}$ The Gallup data can be retrieved from http://www.pollingreport.com/trade.htm.

9"Left-wing" is simply a label intended to capture parties with an anti-business bent. In reality, some anti-business parties are decidedly right-wing. Examples include populist anti-globalization parties such as the Front National in France and the Trumpist wing of the Republican Party in the U.S.
} 
election maximizes the utility of its core constituency by choosing either a business-friendly or a workerfriendly policy. Finally, firms maximize profits by choosing investment levels that reflect the government's policy choice.

Our analysis starts from an equilibrium in which the costs and benefits of remaining listed are equal (so delistings are unprofitable) and the right-wing party is in power. An exogenous reduction in the net benefits of remaining listed and/or in the transactions costs of delistings make it worthwhile for the PE firm to offer to buy out stock market listed companies. If the rate of delistings reaches the point at which middle-class citizens own too few shares in public firms to care about the government continuing to be business friendly, the left-wing party will be voted into power and policy will favor workers over shareholders and entrepreneurs. Aggregate investment in the economy declines as a result. Everyone loses out from the reduction in aggregate investment - the size of the economic "pie" shrinks—but workers receive an offsetting benefit: as government policy shifts in their favor, workers grab a larger share of the shrinking pie in the form of higher wages. Middle-class citizens, whose change in voting behavior triggered the change in policy, optimally trade off the reduction in corporate investment and hence capital income against the gains from selling out to the PE firm and the increase in their wages when policy changes. The main losers are the entrepreneurs who own the private firms in the economy. ${ }^{10}$

The key to understanding why delistings can be both privately optimal and socially excessive lies in the externalities that the delisting decisions give rise to. Delistings reflect the privately optimal decisions of the actor taking firms private and of the target firms' shareholders. Both ignore the effects of their decisions on others, such as workers and the owners of other firms whose utility enters the social welfare function. As a result of this misalignment of interests, investment, productivity, and employment in the economy fall. ${ }^{11}$

Our results are robust to allowing the middle class to reinvest the proceeds from the delisting bids in other public firms. The intuition is simple: investable stock market wealth falls as delistings occur, both because the supply of publicly traded equity is necessarily reduced when firms are delisted and because the change in government (and hence in business friendliness) reduces the profits of the remaining public firms and thus their market values. As a result, incentives to care about capitalism fall even if middle-class citizens

\footnotetext{
${ }^{10}$ In an extension, we show that unemployment increases, making some workers worse off as well.

${ }^{11}$ In addition, the model identifies three further externalities contributing to delistings potentially becoming socially excessive. First, firms choose investment levels to maximize returns to their shareholders, ignoring other potential beneficiaries of investment such as workers. Second, the party in power sets business policy to maximize the utility of the citizens who vote for it, ignoring the effects of its policy choices on citizens voting for the other party. Third, when choosing which party to vote for, a citizen maximizes her own utility, ignoring the effects her vote has on the utility of the other citizens.
} 
were to reshuffle their portfolios across the remaining public firms. This remains the case if middle-class citizens own shares indirectly through mutual funds or 401(k) pension plans: as the investable wealth falls, so does exposure to corporate profits.

It might be argued that delistings would not change the political equilibrium if middle-class citizens had exposure to privately held firms, say through their pension funds. A delisting would simply move a company from one part of their portfolio (public equity) to another part of their portfolio (private equity). Though their exposure to the stock market would be reduced, what matters for their voting behavior is their exposure to corporate profits, which would remain unchanged. This argument is, however, erroneous. Middle-class exposure to corporate profits does decline, for two reasons. First, to the extent that entrepreneurs and workers share in the pension assets, the middle class would go from owning a delisting firm outright to indirectly owning a share equal to the share of middle-class citizens in the economy. Their exposure to corporate profits is thus necessarily diluted. Second, any fees the PE firm charges the pension fund further dilutes middle-class exposure to corporate profits.

Our model is also robust to relaxing the assumption that the middle class holds well diversified portfolios consisting of an equal share of every listed firm. In an extension, we analyze the case of concentrated portfolios when the middle-class citizens who sell are pivotal for the election outcome. This allows us to show that middle-class citizens who sell out to the PE firm not only impose an externality on entrepreneurs when delistings change the election outcome, but also on the middle-class shareholders of firms that remain listed. Intuitively, when portfolios are concentrated, middle-class citizens who are pivotal and sell their shares to the PE firm impose an externality on other middle-class citizens who happen not to own shares in the companies targeted by the PE firm. Because the latter have no say in the delisting decision, their utility is not accounted for. In contrast to entrepreneurs, however, these middle-class citizens receive wages and thus experience an increase in their labor income when the left-wing party comes to power. Whether they lose out overall depends on whether the effect on their utility of the wage increase is smaller than the loss in capital income resulting from the change in policy.

Our analysis identifies a novel "dark side" of private equity. Private equity is often seen as an agent of creative destruction, helping resources to be reallocated to more productive uses. Jensen (1989) argues that private equity firms improve the financial performance and operational efficiency of the companies they acquire, and plenty of academic studies report evidence in support of this "bright side." Buyouts have, for example, been shown to lead to sizable improvements in accounting profits (Kaplan 1989), management 
practices (Bloom, Sadun, and van Reenen 2015), productivity (Lichtenberg and Siegel 1990, Harris, Siegel, and Wright 2005, Davis et al. 2014), and innovation (Lichtenberg and Siegel 1990, Lerner, Sørensen, and Strömberg 2011). By improving their targets' performance, private equity firms may also put indirect pressure on other companies in the industry to raise their own standards (Jensen 1989, Hsu, Reed, and Rocholl 2012, Bernstein et al. 2015). While we do not deny these economic benefits, our analysis suggests that the tremendous growth of the PE industry over the past four decades could, by shrinking the stock market, give rise to a negative externality that has the potential to outweigh the creative-destruction benefits private equity is thought to generate. ${ }^{12}$

While we cast our model in terms of a PE firm taking firms public and thereby catalyzing a process that could, in time, result in harm to the economy, we view the implications of our analysis as applying more broadly. Any public company that delists, whether with the help of a PE firm or in some other way, contributes, on the margin, to the shrinking of the stock market. The same could be said of any private company that chooses not to go public in the first place and thereby fails to help replenish the shrinking pool of listed firms as firms delist or die. In this sense, we view our model as informative about the wider economic consequences of changes in the net benefits of a stock market listing. As both commentators and scholars have recently noted, the public firm model is falling out of favor, in the wake of increases in regulations often perceived as onerous, such as the 2002 Sarbanes-Oxley Act or the 2010 Dodd-Frank Act, the reduction in competition among investment banks catering to high-growth companies, and technological changes said to prevent smaller firms from developing economies of scale or scope (Gao, Ritter, and Zhu 2013, Doidge, Karolyi, and Stulz 2016). Our model predicts that to the extent these developments contribute to a shrinking stock market, direct individual exposure to corporate profits will be reduced, prompting voters to disengage from the capital component of capitalism and as a result to become less supportive of businessfriendly government policies.

Our modeling approach introduces political economy considerations to the private equity literature. In so doing, it builds on work in the literature on the political determinants of an economy's financial structure. On the topic of privatization of state-owned enterprises, Schmidt (2000) shows that the form of privatization can affect investors' ex post risk of expropriation. Biais and Perotti (2002) focus on what an optimal privatization program looks like from the point of view of a right-wing party that wants to stay in power. Subsequent

\footnotetext{
${ }^{12}$ As others have previously noted, the creative destruction that private equity facilitates may come at the expense of workers who lose their jobs (Shleifer and Summers 1988, Lichtenberg and Siegel 1990, Davis et al. 2014, Olsson and Tåg 2017).
} 
work focuses on protections for investors and workers (Pagano and Volpin 2001, 2006) and on how wealth inequality can affect whether economies develop into bank based or market based economies (Perotti and von Thadden 2006).

Our work differs from this political economy literature in two important ways. First, we focus on delisting decisions taken by private actors, rather than a government's privatization decisions. We thus study how private actors' decisions affect ownership in the economy and thereby influence political outcomes, rather than how a government's political choices (such as how to privatize state-owned enterprises) affect the structure of the economy. Second, we focus on contrasting two separate ownership forms: stock market listed and privately held firms. This allows us to study how these ownership forms interact to produce an externality on the owners of privately held firms when the owners of stock market listed firms agree to be bought out by a PE firm.

\section{A Model of Delistings}

Consider an economy consisting of $\mu$ citizens, a private equity investor, two political parties (which we call the left-wing and the right-wing), and $n+s$ firms.

Citizens. There are three social classes: workers, the middle class, and entrepreneurs. Denote the number of citizens in each group by $\mu_{w}, \mu_{m}$, and $\mu_{e}$, respectively. Both workers and the middle class are employed by the $n+s$ firms. To fix ideas, we can think of the former as blue-collar workers and the latter as white-collar employees. We use the term employees when referring to workers and the middle class collectively. We use the term workers when referring to blue-collar workers in particular. For simplicity, we assume that both groups receive equal wages and focus instead on differences in endowment. Middle-class citizens are endowed with shares in public firms, with ownership split equally among them. We do not distinguish between direct and indirect holdings of public firms, so citizens can own public firms directly, through mutual funds, through employee stock ownership plans, or through retirement accounts such as 401(k)s. ${ }^{13}$ Blue-collar workers, in contrast, have no endowments. The private firms in the economy are owned by entrepreneurs, with ownership split equally among them. Entrepreneurs are "rentiers" who earn

\footnotetext{
${ }^{13}$ In reality, not all middle-class citizens own stocks. However, evidence suggests that the group of citizens who tend to vote overlaps with the group of citizens who participate in the stock market. Both groups are older, more highly educated, and earn more. See Burgar and Monkman (2010), Shearer (2012), and Pew Research Center (2012) for an overview of the characteristics of voters and Investment Company Institute (2008) and the Survey of Consumer Finances (2013) for the characteristics of stock market participants.
} 
capital income from their ownership of private firms but do not work for wages. We assume that no class constitutes a majority of voters.

The stock market. We take the stock market to be a technology that reduces the transaction costs of buying and selling shares in firms and thus enables middle-class citizens to invest in firms. We abstract from other ways in which a stock market benefits the economy. ${ }^{14}$

The private equity investor. There is one atomistic private equity ("PE") investor who possesses a technology that allows him to take public firms private. Specifically, the PE investor can offer to buy out a public firm's shareholders at price $p$ per firm. The firm is only delisted if the PE investor obtains $100 \%$ of the shares. ${ }^{15}$ When taking a firm private, the PE investor incurs a transaction cost $t$. We assume that the PE investor is not financially constrained and does not re-list the public firms at the point of exit.

The political system. The economy is governed through a two-party political system. Each citizen votes for either the left-wing party $(l)$ or the right-wing party $(r) .{ }^{16}$ The party in power determines business policy, $\alpha \in[0,1]$. The right-wing party sets policy to cater to entrepreneurs while the left-wing party sets policy to cater to workers. This assumption does not mean that middle-class citizens have no influence over business policy. In fact, they hold much of the power since their votes determine if the left-wing or the right-wing party forms the government.

A higher $\alpha$ corresponds to a more business-friendly policy that gives less rent to employees. A concrete example of a business-friendly policy is a right-to-work law, common in parts of the U.S. Such a law limits union power by outlawing certain contractual arrangements between unions and employers, including closed shops and compulsory union membership. We assume that business policy affects firm investment. To take policy on labor unions as an example, there is a large literature showing that unionization affects investment,

\footnotetext{
${ }^{14}$ As modeled in prior work, these include the fact that stock markets increase the liquidity of shareholdings, which improves risk allocation in the economy (Levine 1991, Pagano 1993); that they allow resources to be allocated more efficiently by encouraging information to be produced about firms and their prospects (Grossman and Stiglitz 1980; Greenwood and Jovanovic 1990; Holmstrom and Tirole 1993); and that they improve economic efficiency by allowing badly run firms to be taken over (Grossman and Hart 1980; Stein 1988; Scharfstein 1988).

${ }^{15}$ This assumption avoids Grossman and Hart's (1980) free-rider problem. Grossman and Hart show that takeover bids may not always succeed because shareholders have incentives to free ride on value improvements following a takeover. They can do so by not selling their shares unless the buyer agrees to part with all the value improvements the takeover would create. Assuming that the PE investor can only acquire a firm if he obtains $100 \%$ ownership eliminates the free-rider problem since a hold-out could never enjoy the value improvements. There are many other mechanisms that could eliminate the free-rider problem, any of which could be incorporated into our setting, albeit at the cost of increasing the complexity of the model. For example, as Grossman and Hart show, charter provisions that allow the bidder to expropriate some of the value of the hold-out minority's shares will solve the free-rider problem.

${ }^{16}$ See Duverger (1954) and Palfrey (1989) for seminal theoretical analyses of two-party systems.
} 
innovation, and productivity. ${ }^{17}$ Another example is employment protection laws. ${ }^{18}$ A third example, as mentioned in the Introduction, is trade liberalization.

Firms and listing status. Firms differ depending on whether or not they benefit from being listed. There are $n$ firms whose characteristics are such that their benefit of being listed, $b_{n}$, is negative. These could, for example, be firms that would be commercially disadvantaged if they had to publicly disclose details of their operations, financials, or strategic plans. They are hence privately held. There are $s$ firms currently listed on the stock market. (The size of the stock market is thus captured by $s$.) Some of the $s$ firms (a fraction $1-q)$ derive positive net benefits from continuing to be listed $\left(b_{1-q}>0\right)$, for example because the liquidity benefit of having tradable shares outweighs their disclosure costs. Others (a fraction $q \in[0,1]$ ) initially derive positive net benefits but will later be allowed to suffer negative net benefits $\left(b_{q}<0\right)$, making them candidates for a delisting. ${ }^{19}$ In total, there are thus $q s$ stock market listed firms that the PE investor can potentially take private. We use the notation $b_{h}$ with $h \in\{n, 1-q, q\}$ to index firms according to their net benefit of listing.

Firms and investment. Firms choose investment $k$ to maximize net profits from operations $\pi(k)$ plus the net benefits of being listed, $b_{h} \cdot{ }^{20}$ Net profits from operations $\pi(k)$ equal gross profits $g(k)$ (i.e., revenue minus cost of goods sold) less wage costs $w(\alpha, k)$ and capital expenditure $c(k)$. We assume that gross profits $g(k)$ are positive and strictly increasing in investment $k$. The profit resulting from a firm's investment is shared with its employees according to a sharing rule determined by the business policy $\alpha$. Specifically, a firm's aggregate wage bill is $w(\alpha, k)=\bar{w}+(1-\alpha) g(k)$ where $\bar{w}$ is the reservation wage and $(1-\alpha) g(k)$ are "rents" employees appropriate from the firm's investment. Each firm is a monopolist in its own product segment and can perfectly price discriminate, leaving no surplus for citizens consuming its product.

\footnotetext{
${ }^{17}$ For example, using close union election victories in a regression-discontinuity setting, Lee and Mas (2012) show that firms invest less in property, plant, and equipment following union victories, while Bradley, Kim, and Tian (2016) show that union victories lead to less innovation, especially in states in which union bargaining power is high.

${ }^{18}$ In France, for example, such laws apply once a company has at least 50 employees. This threshold has been shown to cause a variety of economic distortions (Garicano, LeLarge, and Van Reenen 2016).

${ }^{19}$ The costs and benefits of being listed can change over a firm's life, as a result of changes in agency costs (Jensen 1989) or the firm's innovation strategy (Ferreira et al. 2014). They can also change as a result of policy interventions, such as changes in disclosure requirements or the ease with which activist shareholders can put pressure on management. Prominent examples from the U.S. include the 2002 Sarbanes-Oxley Act and recent attempts to loosening proxy access rules.

${ }^{20}$ We keep the net listing benefit outside the profit function since many costs and benefits of a stock market listing affect a firm's share price rather than its profits. A prominent example is trading liquidity: being able to buy and sell a firm's shares in a liquid market increases its share price (Amihud and Mendelson 1986) but has no direct bearing on its profits from operations.
} 
Productivity. Labor productivity, $L P$, equals value-added per employee:

$$
L P=[g(k)-c(k)]\left(\frac{\mu_{w}+\mu_{m}}{n+s}\right)^{-1},
$$

where $\frac{\mu_{w}+\mu_{m}}{n+s}$ is the number of employees per firm.

Timing. The game consists of the following four stages:

- at $t=1$, delistings take place;

- at $t=2$, elections take place;

- at $t=3$, business policy is set by the party in power;

- at $t=4$, investments are made, profits are realized, wages are paid, and consumption takes place.

We solve the game through backwards induction. All proofs (including a proof of existence) can be found in the Appendix.

\subsection{Firms' Investment Decisions}

Citizens who are shareholders in a firm of type $h$ instruct the manager to set investment $k$ to maximize the sum of net profits and, if listed, the net benefit of listing:

$$
\max _{k} \pi(\alpha, k)+b_{h}=g(k)-w(\alpha, k)-c(k)+b_{h}
$$

where $w(\alpha, k)=\bar{w}+(1-\alpha) g(k)$. Optimal investment $k^{*}(\alpha)$ is given by the first-order condition $\alpha g^{\prime}\left(k^{*}\right)-$ $c^{\prime}\left(k^{*}\right)=0$. Suppose that the second-order condition $\alpha g^{\prime \prime}\left(k^{*}\right)-c^{\prime \prime}\left(k^{*}\right)<0$ holds. Lemma 1 then follows.

Lemma 1. Optimal investment $k^{*}(\alpha)$ is given by the first-order condition $\alpha g^{\prime}\left(k^{*}\right)-c^{\prime}\left(k^{*}\right)=0$. Investment increases in how business-friendly the government's policy is: $\frac{d k}{d \alpha}>0$.

Proof. See the Appendix.

Business policy affects investment decisions because firms maximize net profits and so fail to internalize the effect investment has on employees through raising employees' wages. ${ }^{21}$ Empirical evidence suggests

\footnotetext{
${ }^{21}$ Shareholders of public firms have an incentive to partly internalize the effect of investment on wages since they also work for wages. However, given that citizens hold a diversified portfolio of shares in all firms, it would be difficult for them to coordinate
} 
that pro-labor business policies indeed reduce corporate investment. Besley and Burgess (2004), for example, show that manufacturing firms in Indian states that implemented pro-labor policies reduced investment levels relative to comparable firms in other Indian states. There is also evidence that corporate investment generates positive spillovers for employees. For example, Blanchflower, Oswald, and Sanfey (1996) show that wages at U.S. manufacturing firms increase following profitability-increasing investments, while Van Reenen (1996) shows that wages at U.K. firms increase after investments in innovation.

\subsection{Business Policy in Equilibrium}

Business policy is set by the party in power. As noted earlier, a right-wing government caters to entrepreneurs, while a left-wing government caters to workers. Since there are $\mu_{m}+\mu_{w}$ employees and $n+s$ firms, each worker earns a wage equal to $\frac{n+s}{\mu_{m}+\mu_{w}} w\left(\alpha, k^{*}(\alpha)\right)$. Entrepreneurs earn capital income in the form of the net profits of the private firms they own. Since there are $n$ such firms and $\mu_{e}$ entrepreneurs, each entrepreneur earns capital income equal to $\frac{n}{\mu_{e}} \pi\left(\alpha, k^{*}(\alpha)\right)$. The utility functions the left-wing and the right-wing parties maximize are thus:

$$
\begin{aligned}
U_{w}\left(\alpha, k^{*}(\alpha)\right) & =\frac{n+s}{\mu_{m}+\mu_{w}} w\left(\alpha, k^{*}(\alpha)\right), \\
U_{e}\left(\alpha, k^{*}(\alpha)\right) & =\frac{n}{\mu_{e}} \pi\left(\alpha, k^{*}(\alpha)\right),
\end{aligned}
$$

where $U_{w}$ denotes the utility of a worker and $U_{e}$ the utility of an entrepreneur. As the following lemma shows, the left-wing party prefers to set a less business-friendly policy than the right-wing party.

Lemma 2. A left-wing government is less business-friendly than a right-wing government: $0<\alpha_{l}^{*}<\alpha_{r}^{*}=1$. As a result, the election of a left-wing government leads to higher wages but lower investment and lower net profits in the economy: $\Delta_{w}^{*}=w_{l}^{*}-w_{r}^{*}>0, k_{l}^{*}<k_{r}^{*}$, and $\Delta_{\pi}^{*}=\pi_{l}^{*}-\pi_{r}^{*}<0$, where $w_{j}^{*}=w\left(\alpha_{j}^{*}, k^{*}\left(\alpha_{j}^{*}\right)\right)$, $\pi_{j}^{*}=\pi\left(\alpha_{j}^{*}, k^{*}\left(\alpha_{j}^{*}\right)\right)$, and $j \in\{r, l\}$.

Proof. See the Appendix.

Intuitively, the right-wing party prefers a more business-friendly policy because it caters to entrepreneurs whose utility, through their ownership of private firms, depends on corporate profits. The left-wing party,

on what the firm's objective should be if not to maximize net profit. Only in the extreme case that each firm employed a single worker who was also the firm's sole shareholder would investment decisions fully internalize the effect of investment on wages. In this extreme case, business policy would have no effect on investment. However, most firms have more than one worker and every public firm has more than one shareholder, ensuring that the lemma holds in practice. 
catering to workers, cares only about wages. It is not the case, however, that the left-wing government would choose a policy that expropriated all returns from investment. The left-wing government realizes that its choice of business policy will affect investment, which in turn affects wages; if all returns went to employees, firms would choose not to invest. As a result, $\alpha_{l}^{*} \neq 0$. Clearly, the left-wing party will not want to give all returns to shareholders $\left(\alpha_{l}^{*}=1\right)$, since doing so would push wages down to the reservation wage $w=\bar{w}$, below the wage level when $\alpha_{l}^{*}<1$.

\subsection{The Political Equilibrium}

Each citizen votes for the party that maximizes her utility. Hence, it is immediate that entrepreneurs vote for the right-wing party while workers vote for the left-wing party. The political battleground is thus in the middle. A middle-class citizen's utility — and thus choice of party to vote for-depends on whether or not delistings have taken place. A middle-class citizen obtains utility equal to

$$
U_{m}= \begin{cases}\frac{n+s}{\mu_{m}+\mu_{w}} w+\frac{(1-q) s}{\mu_{m}}\left(\pi+b_{1-q}\right)+\frac{q s}{\mu_{m}} p & \text { with delistings } \\ \frac{n+s}{\mu_{m}+\mu_{w}} w+\frac{(1-q) s}{\mu_{m}}\left(\pi+b_{1-q}\right)+\frac{q s}{\mu_{m}}\left(\pi+b_{q}\right) & \text { without delistings. }\end{cases}
$$

In this expression, we use the shorthand $w=w\left(\alpha, k^{*}(\alpha)\right)$ and $\pi=\pi\left(\alpha, k^{*}(\alpha)\right)$. The first term represents wage income from the $n+s$ firms split among the $\mu_{m}+\mu_{w}$ employees. The second term represents capital income in the form of the net profits from the $(1-q) s$ public firms that remain listed and that the middle class thus continue to own, split among the $\mu_{m}$ middle-class citizens. The final term differs depending on whether or not delistings have taken place. If they have, the final term represents the payment a middle-class citizen receives from the PE investor when selling her shares of the $q s$ public firms that are delisted. Otherwise, the final term represents a middle-class citizen's share of the net profits and the net listing benefits of the $q s$ firms that now remain listed.

We start our analysis in an equilibrium in which, absent delistings, the middle-class citizens would vote for the right-wing party. Assuming that an indifferent middle-class citizen votes left, this would happen if $\frac{n+s}{\mu_{m}+\mu_{w}} \Delta_{w}^{*}+\frac{s}{\mu_{m}} \Delta_{\pi}^{*}<0$ (from equation (5)). In the presence of delistings, we can characterize the election outcome as follows:

Lemma 3. If delistings take place, a middle-class citizen votes for the left-wing party if $\frac{n+s}{\mu_{m}+\mu_{w}} \Delta_{w}^{*}+\frac{(1-q) s}{\mu_{m}} \Delta_{\pi}^{*} \geq$ 0 , and otherwise for the right-wing party. Thus, the more firms that delist (a larger q), the more likely it is 
that the left-wing party wins the election.

This lemma follows by comparing a middle-class citizen's income in equation (5) from voting left (resulting in business policy $\alpha_{l}^{*}$ ) or voting right (resulting in business policy $\alpha_{r}^{*}$ ). The condition in Lemma 3 clarifies that the election outcome depends on the difference in a middle-class citizen's wage and capital income under left-wing versus right-wing rule. Left-wing rule increases wages, $\Delta_{w}^{*}>0$, while reducing net profits, $\Delta_{\pi}^{*}<0$. When more firms delist (that is, when $q$ increases), net profits start to matter less to a middle-class citizen and she thus becomes more likely to vote left. ${ }^{22}$

Empirical evidence supports the idea that voting behavior is affected by stockholdings. Using demutualizations of telecommunications firms in Finland, Kaustia, Knüpfer, and Torstila (2016) show that owning shares in publicly listed firms increases the probability of voting for a right-of-center party.

\subsection{When do Delistings Happen?}

In the delisting stage, the PE investor has the opportunity to buy $q s$ public firms at a price $p$ per firm. To solve the delisting game, we characterize the set of prices for which the PE investor and the middle-class citizens who own these firms are willing to complete a buyout transaction. This corresponds to the set of prices such that the agreed price is lower than or equal to the PE investor's maximum willingness to pay and higher than or equal to the middle-class citizens' reservation price.

There are two cases to consider, depending on whether or not delistings affect the election outcome. A change in the election outcome from right to left will take place when the following condition holds.

Condition 1. The election outcome changes from right-wing to left-wing as a result of delistings when

$$
\frac{n+s}{\mu_{m}+\mu_{w}} \Delta_{w}^{*}+\frac{(1-q) s}{\mu_{m}} \Delta_{\pi}^{*} \geq 0>\frac{n+s}{\mu_{m}+\mu_{w}} \Delta_{w}^{*}+\frac{s}{\mu_{m}} \Delta_{\pi}^{*}
$$

Condition 1 states that our conclusions do not require that all firms delist from the stock market. All we need for our conclusions to hold is that the size of a middle-class voter's exposure to corporate profits declines such that Condition 1 holds. The left-hand side of the condition is required for the middle class to vote left when delistings take place. The right-hand side of the condition ensures that absent delistings,

\footnotetext{
${ }^{22}$ If we allowed the middle class to own shares in private firms as well as public ones (say, through an employee stock ownership plan or incentive-based stock options), net profits would start to matter more and thus the middle class would be less likely to vote left, on the margin.
} 
we are in an equilibrium with the right-wing party in power. If the left-hand side of Condition 1 fails to be satisfied (i.e., if $q$ is small such that few firms delist), the middle class will continue to vote for the right-wing party even when delistings take place.

Suppose Condition 1 holds. For each delisted firm, the PE investor obtains profits $\pi\left(\alpha, k^{*}(\alpha)\right)$ net of transaction costs $t$ and the price $p$ paid for the shares. Denote by $U_{p e}(\alpha, q)$ the PE investor's utility under business policy $\alpha$ when taking $q s$ firms private at transaction cost $t$ per firm. We have

$$
U_{p e}(\alpha, q)=q s\left(\pi\left(\alpha, k^{*}(\alpha)\right)-t-p\right)
$$

Knowing that delistings shift business policy, the PE investor is willing to buy all shares of the qs firms at a price $p_{p e}$ per firm such that $U_{p e}\left(\alpha_{l}^{*}, q\right) \geq U_{p e}\left(\alpha_{r}^{*}, 0\right)$. This gives

$$
p_{p e} \leq \pi_{l}^{*}-t
$$

The PE investor's maximum willingness to pay increases in a firm's net profit under a left-wing government $\pi_{l}^{*}$ and decreases in the transaction cost $t$.

A middle-class citizen has a reservation price for selling her shares, $p_{m}$, such that $U_{m}\left(\alpha_{l}^{*}, q\right) \geq U_{m}\left(\alpha_{r}^{*}, 0\right)$. Using equation (5), we can write this inequality as follows:

$$
\underbrace{\frac{n+s}{\mu_{m}+\mu_{w}} w_{l}^{*}+\frac{(1-q) s}{\mu_{m}}\left(\pi_{l}^{*}+b_{1-q}\right)+\frac{q s}{\mu_{m}} p_{m}}_{\text {Sell shares, left-wing party wins election }} \geq \underbrace{\frac{n+s}{\mu_{m}+\mu_{w}} w_{r}^{*}+\frac{(1-q) s}{\mu_{m}}\left(\pi_{r}^{*}+b_{1-q}\right)+\frac{q s}{\mu_{m}}\left(\pi_{r}^{*}+b_{q}\right)}_{\text {Do not sell shares, right-wing party stays in power }}
$$

Solving for $p_{m}$, we obtain

$$
p_{m} \geq \pi_{r}^{*}+b_{q}-\frac{\mu_{m}}{q s}\left[\frac{n+s}{\mu_{m}+\mu_{w}} \Delta_{w}^{*}+\frac{(1-q) s}{\mu_{m}} \Delta_{\pi}^{*}\right]
$$

This expression clarifies that the middle-class citizens' reservation value of delisting the $q s$ firms not only depends on the net profits and the net listing benefits of each of the $q s$ firms, $\pi_{r}^{*}+b_{q}$, but also on the changes in their wages and in the capital income they receive from the $(1-q) s$ firms that remain listed. Middle-class citizens realize that if they sell out to the PE investor, they will have an incentive to vote for the left-wing party, causing a shift in business policy. A shift from right-wing to left-wing business policy causes wages 
to increase $\left(\Delta_{w}>0\right)$, which reduces the reservation price $p_{m}$. It also causes profits at the remaining $(1-q) s$ listed firms to fall $\left(\Delta_{\pi}<0\right)$, which increases the reservation price $p_{m}$.

By relating the reservation price, $p_{m}$, to the PE investor's maximum willingness to pay, $p_{p e}$, we obtain a condition for when there exists a price $p$ such that the middle-class citizens and the PE investor can agree on delisting qs firms when doing so leads to a change in government and hence in business policy. That is, there exists a price such that delistings are privately optimal.

Condition 2. Delistings are privately optimal when

$$
\frac{n+s}{\mu_{m}+\mu_{w}} \Delta_{w}^{*}+\frac{(1-q) s}{\mu_{m}} \Delta_{\pi}^{*}+\frac{q s}{\mu_{m}}\left(\Delta_{\pi}^{*}-b_{q}-t\right) \geq 0
$$

This condition captures the effects of a change in the election outcome on wages and listed firms' net profits. The first term is positive: delistings increase wages as policy becomes less business-friendly. The second term is negative: the net profits of the $(1-q) s$ firms that remain listed fall. The final term captures the effect of delistings on profits net of the listing benefits and the transaction cost of delisting. Delistings cause the net profits of delisting firms to fall by $\Delta_{\pi}^{*}$, make the (negative) net benefits of a continued listing $b_{q}$ disappear, and incur a positive transaction cost $t$. If the sum of these three terms is positive, the middle class and the PE investor are each weakly better off if delistings take place and so delistings are privately optimal.

For delistings that change the election outcome to take place, we need Conditions 1 and 2 to hold simultaneously. That is, we need delistings to change the election outcome and to also be privately optimal. The following proposition characterizes the circumstances in which both conditions hold simultaneously.

Proposition 1. Delistings that change the election outcome are more likely to take place when transaction costs $t$ are low, when $-\left(b_{q}+t\right)>0$ and the share of listed firms that are worth delisting $q$ is high, and when these firms' net benefits of remaining listed $b_{q}$ are sufficiently negative. Holding constant the total number of firms in the economy, delistings are also more likely to change the election outcome when the stock market is smaller (i.e., when s is low) as long as $\frac{n+s}{\mu_{m}+\mu_{w}} \Delta_{w}^{*}+\frac{s}{\mu_{m}} \Delta_{\pi}^{*} \leq 0$ and $\frac{1-q}{\mu_{m}} \Delta_{\pi}^{*}+\frac{q}{\mu_{m}}\left(\Delta_{\pi}-b_{q}-t\right)>0$.

Proof. See the Appendix.

Proposition 1 summarizes the parameter values for which Conditions 1 and 2 hold simultaneously. First, delistings need to change the election outcome. This happens when the number of firms that can be delisted 
$q s$ is sufficiently large such that delistings have a large effect on voting behavior. Second, it must be profitable for the PE investor to offer to delist the firms. This happens when transaction costs $t$ are low and/or the net benefits of remaining listed $b_{q}$ are sufficiently negative.

Third, stock market size can affect whether delistings change the election outcome. A larger stock market (i.e., a greater number of listed firms) makes the middle class less willing to sell out to the PE investor, since they will then remain shareholders in a relatively large number of firms that remain listed and so are affected by the change in business policy. (This effect is captured by the term $\frac{1-q}{\mu_{m}} \Delta_{\pi}^{*}$.) At the same time, a larger stock market also means that potentially more firms can delist, increasing the benefits the middle class can earn from delistings. (This effect is captured by the term $\frac{q}{\mu_{m}}\left(\Delta_{\pi}-b_{q}-t\right)$.) If the latter effect dominates the former, then a smaller stock market increases the likelihood that delistings will take place as Condition 2 is more likely to hold.

Combining Proposition 1 with Lemmas 1 and 2, we obtain the following six empirical predictions:

Corollary 1. When delistings that change the election outcome occur, delistings lead to:

(i) a reduction in the government's business friendliness: $\alpha_{l}^{*}-\alpha_{r}^{*}<0$;

(ii) a reduction in aggregate investment: $[n+s]\left(k\left(\alpha_{l}^{*}\right)-k\left(\alpha_{r}^{*}\right)\right)<0$;

(iii) a reduction in aggregate profits: $[n+s] \Delta_{\pi}^{*}<0$;

(iv) a reduction in labor productivity: $\frac{\left(g\left(k_{l}\right)-c\left(k_{l}\right)\right)-\left(g\left(k_{r}\right)-c\left(k_{r}\right)\right)}{\frac{\mu_{w}+\mu_{m}}{n+s}}<0$;

(v) a fall in the share prices of the firms that remain listed; and

(vi) an increase in total wages in the economy: $[n+s] \Delta_{w}>0$.

The causal chain of events predicted by our model is that delistings reduce middle-class citizens' income from shareholdings, which changes their voting behavior and helps the left-wing party, with its less businessfriendly and more worker-friendly agenda, come to power. Every firm in the economy then responds to the ensuing policy change by reducing investment. The profits of all firms in the economy fall as a result, as does labor productivity. ${ }^{23}$ As soon as Conditions 1 and 2 hold simultaneously, the share prices of the remaining listed firms fall by an amount equal to the capitalized value of the reduction in profits going forward. Finally, wages throughout the economy increase as the newly elected government enacts worker-friendly policies to benefit its worker constituency.

\footnotetext{
${ }^{23}$ Though outside the model, profits and productivity at the delisting firms could in reality increase as a result of managerial and other improvements under private ownership. Allowing for this would make the expressions more cumbersome without changing the results.
} 
These predictions hold only when delistings change the election outcome. But delistings that do not change the election outcome can take place as well. Such delistings take place when delistings are privately profitable (Condition 2 holds) but do not affect the election outcome (Condition 1 fails to hold). In this case, business friendliness, corporate investment, net profits, the share prices of the remaining listed firms, and wages remain unchanged. Thus, delistings do not always lead to the effects outlined in Corollary 1; they only do so when a tipping point is reached.

\section{Winners and Losers}

Who gains and who loses from delistings? To get an intuition for this, we analyze total surplus in the economy. Total surplus equals the sum of the individual utilities generated in the economy:

$$
T S=\mu_{e} U_{e}+\mu_{m} U_{m}+\mu_{w} U_{w}+U_{p e}
$$

This expression can be rewritten as:

$$
T S(\alpha)= \begin{cases}(n+s)(w+\pi)+(1-q) s b_{1-q}-q s t & \text { with delistings } \\ (n+s)(w+\pi)+(1-q) s b_{1-q}+q s b_{q} & \text { without delistings. }\end{cases}
$$

When there is a change in the election outcome (i.e., when Condition 1 holds), delistings will increase total surplus if

$$
(n+s)\left[w_{l}^{*}+\pi_{l}^{*}\right]+(1-q) s b_{1-q}-q s t \geq(n+s)\left[w_{r}^{*}+\pi_{r}^{*}\right]+(1-q) s b_{1-q}+q s b_{q} .
$$

This expression can be rewritten to obtain a condition for when delistings are socially optimal, i.e., when they lead to higher total surplus.

Condition 3. Delistings are socially optimal when

$$
(n+s)\left(\Delta_{w}^{*}+\Delta_{\pi}^{*}\right)-q s\left(b_{q}+t\right) \geq 0
$$

According to Lemma 1 and Lemma 2, the first term in Condition 3 is negative. The intuition is as 
follows. A left-wing government is less business friendly than a right-wing government. This leads to an increase in firms' wage bills $\left(\Delta_{w}>0\right)$ since $w(\alpha)$ is maximized at $\alpha_{l}^{*}$. We also know that net profits are lower under a left-wing government $\left(\Delta_{\pi}<0\right)$ since net profits are increasing in $\alpha\left(\frac{d \pi}{d \alpha}>0\right)$ and $\alpha_{l}^{*}<\alpha_{r}^{*}$. Importantly, the negative effect of a left-wing election victory on net profits strictly outweighs the positive effect on wages. The reason is that gross profits net of capital expenditures, $g(k)-c(k)$, which are to be split between wages and capital income paid to shareholders, will fall as investment drops from $k^{*}\left(\alpha_{r}\right)$ to $k^{*}\left(\alpha_{l}\right)$. Because the $n+s$ firms are symmetric, the sum of aggregate wages and aggregate net profits also drops (i.e., $\left.(n+s)\left(\Delta_{w}+\Delta_{\pi}\right)<0\right)$. The second term in Condition 3 can be positive or negative, depending on the relative size of the (negative) net benefit of staying listed $b_{q}$ and the transaction cost $t$. Delistings are thus socially optimal if they produce a large enough saving, net of transaction costs, to compensate for the fall in investment.

Next, decompose Condition 3 into the effects of delistings on entrepreneurs, the middle class and the PE investor, and workers:

$$
\begin{array}{r}
(n+s)\left(\Delta_{w}^{*}+\Delta_{\pi}^{*}\right)-q s\left(b_{q}+t\right) \geq 0 \\
\underbrace{\mu_{e} \frac{n}{\mu_{e}} \Delta_{\pi}^{*}}_{\text {Entrepreneurs }}+\underbrace{\mu_{m}\left[\frac{n+s}{\mu_{m}+\mu_{w}} \Delta_{w}^{*}+\frac{(1-q) s}{\mu_{m}} \Delta_{\pi}^{*}+\frac{q s}{\mu_{m}}\left(\Delta_{\pi}^{*}-b_{q}-t\right)\right]}_{\text {The middle class and the PE investor }}+\underbrace{\mu_{w} \frac{n+s}{\mu_{m}+\mu_{w}} \Delta_{w}^{*}}_{\text {Workers }} \geq 0
\end{array}
$$

The middle three terms in equation (14) (i.e., the effect on the middle class and the PE investor) coincide with Condition 2. This way of writing Condition 3 makes it clear that delistings are coupled with negative externalities on entrepreneurs (who do not work and only receive income from their ownership of the private firms) and with positive externalities on workers (who earn only labor income). Delistings reduce entrepreneurs' capital income as business policy becomes less friendly, reducing profits $\left(\Delta_{\pi}^{*}<0\right)$. Delistings increase workers' labor income as their wages increase $\left(\Delta_{w}^{*}>0\right)$.

Proposition 2. Allocative effects: Delistings that change the election outcome hurt entrepreneurs, weakly benefit the middle class and the PE investor, and benefit workers. Delistings that do not change the election outcome weakly benefit the middle class and the PE investor but do not affect entrepreneurs and workers.

Intuitively, delistings that change the election outcome have three effects on income. First, the change in government from the right-wing party to the left-wing party results in a more redistributive policy (a smaller $\alpha$ ), which favors wage earners over those earning only capital income. Second, delistings lead to a fall in 
the sum of aggregate wages and aggregate net profits as aggregate investment in the economy is reduced as a result of the change in government. This reduction in the economy's productive capacity hurts all citizens, regardless of their class. Third, delistings generate a surplus equal to $q s\left(-b_{q}-t\right)$ as delisting the $q s$ firms avoids having to incur the net listing "benefits" $b_{q}$, which are negative whenever delistings are profitable. This weakly benefits the middle class and the PE investor.

Thus, all of the social costs associated with delistings fall on entrepreneurs. Entrepreneurs lose out because they have no way to prevent delistings from happening: they are not involved in the delisting negotiations and they have too few votes to affect the election outcome, and hence business policy, by themselves. Proposition 2 thus offers the empirical prediction that entrepreneurs have a strong incentive to keep the stock market vibrant, to lobby against increases in the regulatory burden and other costs imposed on listed companies, and to stop companies from delisting, even though (in our model) they do not own any shares in listed companies. The middle class, the PE investor, and workers, on the other hand, will welcome delistings and a shrinking stock market. ${ }^{24}$

\section{When are Delistings Excessive?}

While delistings reduce aggregate investment and labor productivity in the economy, they have an ambiguous effect on total welfare. The reason is that delisting a firm eliminates the cost of being listed, so there are direct welfare benefits of delisting in addition to the indirect negative effects that operate through changes in business policy. The following proposition summarizes when delistings become excessive, that is, when the private and the social incentives to delist firms from the stock market do not coincide.

Proposition 3. Welfare effects: Define delistings as excessive when they change the election outcome (Condition 1 holds) and are privately optimal (Condition 2 holds) but not socially optimal (Condition 3 does not hold). Then the likelihood of the rate of delistings turning excessive:

(i) first increases and then decreases in the cost savings of delisting firms, $-\left(b_{q}+t\right)$;

(ii) increases in stock market participation, $\frac{\mu_{m}}{\mu_{m}+\mu_{w}}$;

(iii) decreases in s, the size of the stock market, holding constant the total number of firms in the economy,

\footnotetext{
${ }^{24}$ Given that the costs and benefits of delistings affect workers, the middle class, and entrepreneurs differently, it is natural to wonder what happens to income inequality. The answer turns out to be ambiguous: inequality could rise or fall. Measuring inequality as the percentage difference between median (i.e., middle-class) income and average income, income inequality will increase if the gains from delistings are large and the PE investor grabs most of the gains. Otherwise, income inequality will fall.
} 
as long as $\frac{n+s}{\mu_{m}+\mu_{w}} \Delta_{w}^{*}+\frac{s}{\mu_{m}} \Delta_{\pi}^{*} \leq 0$ and $\frac{1-q}{\mu_{m}} \Delta_{\pi}^{*}+\frac{q}{\mu_{m}}\left(\Delta_{\pi}-b_{q}-t\right)>0$.

Proof. See the Appendix.

The proposition outlines three sets of conditions under which delistings are likely to turn excessive. To see the intuition for the prediction in part (i), recall Condition 3, according to which the overall welfare effects of delistings depend on how large the cost savings of taking firms private are in relation to the loss in aggregate income from reduced investment. When the cost savings are sufficiently large, delistings are always socially desirable. When they are small, delistings that change the election outcome cannot take place since they are not privately profitable (Condition 2 does not hold). Thus, the private and social incentives for delistings can only diverge (and so delistings can only become excessive) when the cost savings are in an intermediate range.

There are two reasons why delistings are more likely to become excessive the greater is stock market participation. First, recall that delistings that change the election outcome benefit workers by raising their wages. This positive externality is smaller the fewer workers there are in the economy (which in our setup means: the higher is stock market participation). A smaller positive externality on workers makes it more likely that the overall welfare effects are negative and thus that delistings are excessive. Second, the private incentives to delist firms depend in part on the increase in wages from delistings that accrues to the middle class. When the middle class is large (which in our model corresponds to high stock market participation), a greater share of labor income (and hence of the increase in wages) accrues to the middle class. Private incentives to delist firms thus increase while social incentives remain unchanged, making it more likely that delistings are excessive.

To see why a smaller stock market, $s$, makes excessive delistings more likely, holding constant the total number of firms in the economy, note that fewer listed firms means there are more private firms $n$ owned by entrepreneurs. As Proposition 2 states, entrepreneurs are hurt when delistings change the election outcome. Since there are more of them when the stock market is small, the negative externality on entrepreneurs is greater, the social incentives to delist firms are lower, and thus the rate of delistings is more likely to turn excessive. Under the same conditions as in Proposition 1, however, a reduction in the size of the stock market increases the private incentive to delist firms and so makes it more likely that delistings will change the election outcome. Thus, under these conditions, if there are fewer listed firms, then private and social incentives to delist are more likely to diverge. Excessive delistings then become more likely. 
For completeness, note that there are parameter values for which the rate of delistings can be too low socially. This can occur when the middle class and the PE investor would be worse off if a socially desirable delisting went ahead (Condition 2 fails to hold but Conditions 1 and 3 hold).

\section{Extensions}

\subsection{Allowing the Middle Class to Invest in Private Equity}

It might be argued that delistings would not change the political equilibrium if the PE investor internalized the interests of the middle class, such as when the PE investor manages pension funds on behalf of the citizens in the economy. A delisting would then simply move a company from one part of middle-class citizens' portfolios (public equity) to another part of their portfolios (private equity). Though their exposure to the stock market would be reduced, what matters for the way middle-class citizens vote is their exposure to corporate profits, which would remain unchanged. The right-wing party would thus remain in power after the election.

This argument is, however, erroneous. In fact, middle-class exposure to corporate profits would still decline, for two reasons. First, to the extent that entrepreneurs and workers share in the pension assets, the middle class would go from owning the delisting firms outright to indirectly owning a share equal to the share of middle-class citizens in the economy. Second, any fees the private equity investor charges for managing the pensions would further dilute middle-class exposure to corporate profits.

To formalize this argument, suppose that the PE investor continues to maximize profits from taking firms private, as in the baseline model, but instead of keeping the gains from delisting distributes these gains equally among all citizens, less a management fee of $f$ percent. $^{25}$ This means that the utility functions of entrepreneurs, workers, and the middle class have an additional term equal to $\frac{1}{\mu}(1-f)$ times the gains from delisting, where $\mu=\mu_{e}+\mu_{m}+\mu_{w}$. We obtain the following proposition.

Proposition 4. The rate of delistings can be excessive even when the PE investor invests pension money and the PE investor captures a fraction $f$ of the gains from delisting the firms. This occurs when the left-wing party comes to power and delistings are privately but not socially optimal. Formally, denote the change in wages and profits as we go from a right-wing to a left-wing government by $\Delta_{w p}^{*}$ and $\Delta_{\pi p}^{*}$. The election

\footnotetext{
${ }^{25}$ In practice, PE funds typically charge their investors an annual management fee of around 1-2\% of assets under management in addition to a performance fee (the "carried interest") of typically $20 \%$ of capital gains. For a model of how these fees are set in equilibrium, see Hochberg, Ljungqvist, and Vissing-Jorgensen (2014).
} 
outcome will then change if

$$
\frac{n+s}{\mu_{m}+\mu_{w}} \Delta_{w p}^{*}+\frac{(1-q) s}{\mu_{m}} \Delta_{\pi p}^{*}+\frac{1}{\mu}(1-f) q s \Delta_{\pi p}^{*} \geq 0>\frac{n+s}{\mu_{m}+\mu_{w}} \Delta_{w}^{*}+\frac{s}{\mu_{m}} \Delta_{\pi}^{*}
$$

delistings will be privately optimal if

$$
\pi_{l}^{*}-t-\left[\frac{q s}{\mu_{m}}-\frac{(1-f) q s}{\mu}\right]^{-1}\left[\frac{q s}{\mu_{m}}\left[\pi_{r}^{*}+b_{q}\right]-\frac{(1-f)}{\mu} q s\left[\pi_{l}^{*}-t\right]-\frac{n+s}{\mu_{m}+\mu_{w}} \Delta_{w}^{*}-\frac{(1-q) s}{\mu_{m}} \Delta_{\pi}^{*}\right] \geq 0
$$

and delistings will be socially sub-optimal if

$$
(n+s)\left(\Delta_{w p}^{*}+\Delta_{\pi p}^{*}\right)-q s\left(b_{q}+t\right)<0 .
$$

Proof. See the Appendix.

Proposition 4 shows that our results are robust to allowing the PE investor to manage pension assets. A few important subtle effects come into play. To help with the intuition, note that the utility functions that the right-wing government (catering to entrepreneurs) and the left-wing government (catering to workers) maximize when delistings take place are now:

$$
\begin{aligned}
U_{e} & =\frac{n}{\mu_{e}} \pi+\frac{1}{\mu}(1-f) q s(\pi-t-p), \\
U_{w} & =\frac{n+s}{\mu_{m}+\mu_{w}} w+\frac{1}{\mu}(1-f) q s(\pi-t-p) .
\end{aligned}
$$

From these expressions, note first that when each citizen has a stake in the delisted firms through her pension, workers have an incentive to push for more business-friendly policies, unlike in our baseline model, because of the added income from pension holdings (the last term in each expression). This causes the policy differences between the two political parties to shrink. Second, the fee that the PE investor charges to manage pension assets has a direct effect on policy choices since it enters in the last term. The higher the fee, the larger the policy difference because a higher fee makes workers care less about their pension holdings. If the PE investor captures all the gains from delisting $(f=1)$, we are back in the baseline model.

To highlight two further effects, examine equation (14), which splits Condition 3 stating when delistings are socially optimal into the effects on entrepreneurs, the middle class and the PE investor, and workers. The 
updated equation accounting for pension investments reads as follows:

$$
\begin{array}{r}
\underbrace{\mu_{e}\left[\frac{n}{\mu_{e}} \Delta_{\pi p}^{*}+\frac{1}{\mu}(1-f) q s\left(\pi_{l}^{*}-t-p\right)\right]}_{\text {Entrepreneurs }} \\
+\underbrace{\pi_{l}^{*}-t-\left[\frac{q s}{\mu_{m}}-\frac{(1-f) q s}{\mu}\right]^{-1}\left[\frac{q s}{\mu_{m}}\left[\pi_{r}^{*}+b_{q}\right]-\frac{(1-f)}{\mu} q s\left[\pi_{l}^{*}-t\right]-\frac{n+s}{\mu_{m}+\mu_{w}} \Delta_{w}^{*}-\frac{(1-q) s}{\mu_{m}} \Delta_{\pi}^{*}\right]}_{\text {The middle class and the PE investor }} \\
+\underbrace{\mu_{w}\left[\frac{n+s}{\mu_{m}+\mu_{w}} \Delta_{w p}^{*}+\frac{1}{\mu}(1-f) q s\left(\pi_{l}^{*}-t-p\right)\right]}_{\text {Workers }}
\end{array}
$$

A difference to the baseline model is that the externalities on entrepreneurs (the first term) and workers (the last term) here depend on how the gains from delistings are split between the middle class and the PE investor (set by the delisting price, $p$ ). The reason is that this split determines pension payouts to the entrepreneurs and to the workers. Thus, the bargaining power of the PE investor relative to the middle class becomes an important determinant of how large the externalities from delistings are. If the PE investor has all the bargaining power, delistings have additional positive externalities on workers and entrepreneurs. If the middle class has all the bargaining power, then workers' and entrepreneurs' pensions do not increase in value. Note also that the positive externality on workers depends on $\Delta_{w p}^{*}$ instead of $\Delta_{w}^{*}$ and that the negative externality on entrepreneurs depends on $\Delta_{\pi p}^{*}$ instead of $\Delta_{\pi}^{*}$. This implies that in comparison to the baseline model, both positive and negative externalities are smaller when the PE investor manages pension assets.

Despite these changes to the model, delistings can still be excessive in the presence of a PE investor who manages pension assets. This occurs when the conditions in the proposition are fulfilled.

\subsection{Concentrated Portfolios}

In our baseline model, delistings that change the election outcome have an adverse effect only on entrepreneurs, for the simple reason that entrepreneurs have no say in the delisting decisions. In this extension, we relax the assumption that the middle class holds well diversified portfolios consisting of an equal share of every listed firm. Instead, we now analyze the case of concentrated portfolios when the middle-class citizens who sell are pivotal for the election outcome. This allows us to show that middle-class citizens who sell impose an externality not only on entrepreneurs but also on the middle-class shareholders of firms that remain listed.

Formally, we consider two groups of middle-class citizens instead of one. To capture the effect of 
concentrated portfolios in as simple a way as possible, we let the first group own shares only in the qs firms that are candidates for delisting and the second group own shares only in the $(1-q) s$ firms that remain listed. Let the number of middle-class citizens in the two groups be $\mu_{m q}$ and $\mu_{m(1-q)}$, respectively, such that $\mu_{m q}+\mu_{m(1-q)}=\mu_{m}$. Suppose also that $\mu_{m q}$ is large enough such that this group is pivotal in the election. ${ }^{26}$ We then obtain the following proposition.

Proposition 5. Delistings that change the election outcome leave the middle-class citizens who own shares in the delisting firms weakly better off. Workers are strictly better off while entrepreneurs are strictly worse off. Whether such delistings hurt the middle-class citizens who own no shares in the delisting firms depends on the relative magnitudes of the change in their wages and of the change in the profits of firms that remain listed. If $\mu_{m(1-q)}\left[\frac{n+s}{\mu_{m}+\mu_{w}} \Delta w^{*}+\frac{(1-q) s}{\mu_{m(1-q)}} \Delta \pi^{*}\right]<0$, they are worse off.

Proof. See the Appendix.

Intuitively, when portfolios are concentrated, middle-class citizens who sell their shares to the PE investor and are pivotal impose an externality on other middle-class citizens who happen not to own shares in the firms targeted by the PE investor. Because the latter have no say in the delisting decision, their utility is not accounted for. In contrast to entrepreneurs, however, these middle-class citizens receive wages and thus experience an increase in their labor income when the left-wing party comes to power. Whether they lose out overall depends on whether the effect on their utility of the wage increase is smaller than the loss in capital income resulting from the change in policy. Note also that when portfolios are concentrated, it is more likely that the election will bring the left-wing party to power in the wake of delistings. If the $\mu_{m q}$ middle-class citizens who sell are pivotal, they no longer own any shares after the delisting and thus behave like blue-collar workers who receive only labor income.

\subsection{Unemployment}

Our baseline model abstracts from unemployment to make the analysis more tractable. However, it is likely that changes in firms' optimal investment $k$ would not only affect wages per worker, as we have assumed so far, but also firms' demand for labor. Investment and labor demand are likely complements: as firms grow, they likely increase their absolute demand for labor. When this is the case, it follows that a shift to

\footnotetext{
${ }^{26}$ We make this assumption to be able to obtain excessive delistings. If the $\mu_{m q}$ middle-class citizens are not pivotal, they do not determine the outcome of the election and so their delisting decisions cannnot affect the election. When delistings leave the election outcome unchanged, they cannot be excessive.
} 
a left-wing government will not only increase wages per worker but also unemployment, as firms decide to operate at a smaller scale and so have a lower demand for labor than under the right-wing government. The left-wing party will of course internalize this effect and accordingly choose a more business-friendly policy than it otherwise would.

One simple way to capture these effects is to work with the following expected wage function: $E w(\alpha, k)=$ $\rho(k)(\bar{w}+(1-\alpha) g(k))+(1-\rho(k)) \bar{w}=\bar{w}+\rho(k)(1-\alpha) g(k)$, where $\rho$ is the probability of remaining in employment, $\frac{d \rho(k)}{d k}>0$, and the reservation wage $\bar{w}$ can be thought of as the unemployment benefit. It then follows that reductions in firms' optimal investment $k^{*}$ not only depress wages per employee, $w$, but also increase the unemployment rate, $(1-\rho(k))$.

A left-wing government sets $\alpha$ such that $\max _{\alpha} U_{w}\left(\alpha, k^{*}(\alpha)\right)$ with $\alpha \in[0,1]$. The optimal $\alpha_{l}^{*}$ is either one of the corner solutions (i.e., zero or one) or it is determined implicitly by the first-order condition:

$$
\frac{n+s}{\mu_{m}+\mu_{w}}\left[-\rho\left(k^{*}\right) g\left(k^{*}\right)+\left(\rho\left(k^{*}\right)(1-\alpha) g^{\prime}\left(k^{*}\right)+\rho^{\prime}\left(k^{*}\right)(1-\alpha) g\left(k^{*}\right)\right) \frac{d k}{d \alpha}\right]=0,
$$

where $g^{\prime}\left(k^{*}\right) \frac{d k}{d \alpha}>0$ from Lemma 1 and $\rho^{\prime}>0$ by assumption of complementarity between investment and labor demand, and where we assume that the second-order condition holds such that we obtain an interior solution.

Comparing this to the first-order condition in the baseline model,

$$
\frac{n+s}{\mu_{m}+\mu_{w}}\left[-g\left(k^{*}\right)+(1-\alpha) g^{\prime}\left(k^{*}\right) \frac{d k}{d \alpha}\right]=0,
$$

we see that the main trade-off remains unchanged: reducing business friendliness increases the rents paid to employees as captured by the terms $-g\left(k^{*}\right)$ and $-\rho(k) g\left(k^{*}\right)$. Note that the benefit to employees is smaller compared to the baseline, since $\rho<1$. On the other hand, reducing business friendliness also hurts investment and thereby reduces the size of the pie that can be split between capital and labor, as captured by the terms $(1-\alpha) g^{\prime}\left(k^{*}\right) \frac{d k}{d \alpha}$ and $\rho(k)(1-\alpha) g^{\prime}\left(k^{*}\right) \frac{d k}{d \alpha}$, respectively. In addition, the left-wing party has a new incentive not to reduce business friendliness too much since employment levels increase in firm investment, as captured by the term $\rho^{\prime}(1-\alpha) g\left(k^{*}\right)$.

Allowing firms' labor demand to adjust results in a "polarization" of middle-class wages: while some middle-class employees receive higher wages as business policy becomes more worker-friendly, others be- 
come unemployed. This is consistent with the "hollowing out" of the middle class observed in the U.S. since 1980 (see Autor and Dorn (2013)).

\section{Discussion}

\subsection{Central Assumptions}

Our results build on a number of key assumptions. Central is that delistings reflect the privately optimal decisions of the private equity investor and the target firms' shareholders. Both groups ignore the effects of their decisions on others, such as workers and the owners of other firms whose utility enters the social welfare function. For this externality to be present, however, the following three externalities must also be present.

First, firms choose investment levels to maximize returns to their shareholders, ignoring other potential beneficiaries of investment such as workers. In our model, the surplus from investment is split according to a linear sharing rule. This is important, because if the surplus was distributed as a lump sum transfer to workers, there would be no investment distortion. In practice, however, returns from investments are rarely distributed to workers in a simple lump sum transfer but rather take the form of wage increases (see, for example, Blanchflower, Oswald, and Sanfey 1996 and Van Reenen 1996).

Second, the party in power sets business policy to maximize the utility of the citizens who vote for it, ignoring the effects of its policy choices on citizens voting for the other party. Clearly, if business policy was set by the party in power to maximize total surplus in the economy, the election outcome would not affect policy choice. Similarly, another important assumption is that the government's policy set is restricted to business policy only, which is a second-best choice variable. In reality, we could imagine that the government could intervene in the economy in many other ways, potentially including an efficient two-part tax on firms or citizens to achieve its electoral aims.

Third, when choosing which party to vote for, a citizen maximizes her own utility, ignoring the effects her vote has on other citizens' utility. If middle-class citizens cared about the entrepreneurs and the workers, they would not accept the PE investor's delisting bids when the rate of delistings is excessive.

In addition to these three externalities, another important assumption of our model is that the middle class cannot reinvest the proceeds from the delisting bids in other private firms without cost. Otherwise, their incentives to care about business friendliness would remain unchanged. In practice, however, the 
costs of investing in private equity are substantial and such investments are also coupled with minimum investment amount restrictions. In the U.S., for example, investments in private companies can traditionally only be marketed at "accredited investors," that is, high-net-worth individuals. ${ }^{27}$

We can, however, allow for the middle class to reinvest their delisting proceeds in other public firms. The intuition is simple: investable stock market wealth falls as delistings occur, both because the supply of publicly traded equity is necessarily reduced as firms are delisted and because the change in government (and hence in business friendliness) reduces the profits of the remaining public firms and thus their market values. As a result, incentives to care about capitalism fall even if middle-class citizens were to reshuffle their portfolios across the remaining public firms. This remains the case if the middle class owns shares indirectly through mutual funds or $401(\mathrm{k})$ pension plans: as the investable wealth falls, so does exposure to corporate profits.

Finally, we have cast our election stage as a choice between two polar parties. We conjecture that our results would continue to hold in a model with a more continuous policy choice, such that policy could change without a change in election outcomes. One example would be a model in which political parties can fully commit ex ante to a particular business policy before the election. In such a setting, political parties might want to cater to the median voter to win. (The same is true of many models that incorporate lobbying or politicians with policy preferences as long as the politicians care about being elected.) Once the firms have been delisted, the median voter will hold fewer shares and thus will be less likely to prefer a business-friendly policy. Hence, instead of business policy only changing when there is a change in the election outcome, we would get a continuous shift in policy from right to left as more firms delist.

\subsection{Policy Interventions}

Our model identifies what we believe is an important potential externality associated with PE firms delisting companies from the stock market: by shrinking the size of the stock market, PE firms may contribute to a reduction in stock market participation and hence undermine political support for business-friendly policies in future. Government intervention aimed at reducing the rate of delistings or counteracting their effect by increasing the rate of new listings might hence be desirable. At the simplest level, government may consider taxing private equity activity that involves delistings or subsidize venture capital activity that involves new

\footnotetext{
${ }^{27}$ Under current SEC rules, accredited investors are those with a net worth of at least $\$ 1 \mathrm{~m}$ (not including the primary residence) or annual income of at least $\$ 200,000$.
} 
listings (though whether such interventions solve more problems than they create is an open question).

More subtly, current government policies may aggravate the problem we identify, insofar as tax breaks enjoyed by private equity firms (such as the tax deductibility of interest payments on the debt used to fund their buyouts or the generous tax treatment of their profits as capital gains rather than income) contribute to an excessive level of buyout activity. Similarly, policies intended to improve disclosure, transparency, or governance standards at listed firms may be desirable from the point of view of protecting investors but can also increase the cost of remaining listed and so can have the unintended consequence of triggering delistings and a shrinking of the stock market. Our analysis suggests that policy-makers should take this consequence into account when balancing the pros and cons of different regulations of stock market listed firms.

Interfering with private equity firms' delisting decisions could result in welfare losses by reducing the rate of creative destruction in the economy below the socially optimal level. Finetuning the level of delisting activity may well be beyond government's ability due to information frictions and other practical concerns. An alternative way to mitigate the adverse consequences of delistings in that case may be for government to introduce measures that reduce the cost to the public of investing in privately held firms. This might not only increase expected returns on savings but also improve political support for business-friendly policies which in turn could increase the economy's total surplus. ${ }^{28}$ To the extent that investing in private firms is hampered by information asymmetries, policies intended to improve disclosure among private firms may also be desirable.

\section{Conclusions}

Private equity has long been viewed as a valuable part of the creative-destruction process, helping to restructure companies and thereby reallocate economic resources to more productive uses. The most prominent type of private equity transaction — taking stock market listed companies private—has a necessary byproduct: all else equal, it shrinks the size of the stock market. In this paper, we show that delistings (whether triggered by the growth of the private equity industry or by changes in the net benefits of being listed) can set in motion a chain of events that have the potential to hurt the economy. We develop a political-economy model of delistings to identify the conditions under which the private and social incentives to delist firms

\footnotetext{
${ }^{28}$ Recently implemented rules pursuant to Title IV of the 2012 JOBS Act making it easier for private companies to raise capital from non-accredited investors may be a step in this direction.
} 
from the stock market are misaligned. When the rate of delistings becomes socially excessive, delistings inadvertently impose an externality on the economy by reducing citizen-investors' exposure to corporate profits and undermining popular support for business-friendly policies. This, in turn, can reduce aggregate investment, productivity, and employment and thereby reduce total surplus in the economy.

At the heart of our model is the insight that the shareholders of public firms do not internalize the wider economic consequences of their decision to sell out to private equity firms. The main losers are the owners of privately held firms, whom we call entrepreneurs in the model. While we take the existence of privately held firms as given, in reality many entrepreneurs are backed by venture capitalists who would thus share in the adverse consequences of excessive delistings. In this sense, private equity firms can be said to impose a negative externality on venture capital firms.

There are two central components of our analysis that would be interesting to pursue in future research. First, we have not analyzed the optimal size of the stock market by simultaneously allowing for listings and delistings. Extending the model in this direction could provide insights into the determinants of the equilibrium number of firms listed on the stock market. Second, the policy choices available to government in our model are highly stylized. Extending the model to incorporate more complex policy instruments (such as listing standards and delisting rules, corporate governance codes for listed firms, and subsidies to entice firms to go public) could provide insights into what policy instruments might be effective in preventing the rate of delistings from becoming socially excessive.

Finally, the consensus in favor of open markets and business-friendly policies is also under attack by proponents of protectionist trade policies who cater to the losers of globalization. ${ }^{29}$ Since a well functioning stock market helps ensure that the median voter captures some of the gains of globalization through increased share prices, our political-economy approach suggests that a shrinking stock market can contribute to making the economy more vulnerable to a backlash against free trade.

\footnotetext{
${ }^{29}$ Paul Krugman writes that "the conventional case for trade liberalization relies on the assertion that the government could redistribute income to ensure that everyone wins ... the elite case for ever-freer trade is largely a scam, which voters probably sense even if they don't know exactly what form it's taking." (See "A Protectionist Moment?" (March 9, 2016), available at http://krugman.blogs.nytimes.com/2016/03/09/a-protectionist-moment.)
} 


\section{References}

Amihud, Yakov, and Haim Mendelson, 1986, Asset Pricing and the Bid-Ask Spread, Journal of Financial Economics 17, 223-249.

Autor, David H., and David Dorn, 2013, The Growth of Low-Skill Service Jobs and the Polarization of the U.S. Labor Market, American Economic Review 103, 1553-1597.

Axelson, Ulf, Per Strömberg, and Michael Weisbach, 2009, Why are Buyouts Levered? The Financial Structure of Private Equity Firms, Journal of Finance 64, 1549-1582.

Axelson, Ulf, Tim Jenkinson, Per Strömberg, and Michael Weisbach, 2013, Borrow Cheap, Buy High? The Determinants of Leverage and Pricing in Buyouts, Journal of Finance 68, 2223-2267.

Bernstein, Shai, Josh Lerner, Morten Sørensen, and Per Strömberg, 2015, Private Equity and Industry Performance, Management Science, forthcoming.

Besley, Timothy, and Robin Burgess, 2004, Can Labor Regulation Hinder Economic Performance? Evidence from India, Quarterly Journal of Economics 119, 91-134.

Biais, Bruno, and Enrico Perotti, 2002, Machiavellian Privatization, American Economic Review 92, 240258.

Blanchflower, David G., Andrew J. Oswald, and Peter Sanfey, 1996, Wages, Profits, and Rent-sharing, Quarterly Journal of Economics 111, 227-251.

Bloom, Nick, Raffaella Sadun, and John van Reenen, 2015, Do Private Equity Owned Firms Have Better Management Practices?, American Economic Review Papers and Proceedings 105, 442-446.

Bradley, Daniel, Incheol Kim, and Xuan Tian, 2016, Do Unions Affect Innovation?, Management Science, forthcoming.

Burgar, Joanna, and Martin Monkman, 2010, Who Heads to the Polls? Exploring the Demographics of Voters in British Columbia, Victoria: BC Stats.

Davis, Steven J., John Haltiwanger, Kyle Handley, Ron Jarmin, Josh Lerner, and Javier Miranda, 2014, Private Equity, Jobs, and Productivity, American Economic Review 104, 3956-3990. 
Doidge, Craig, Andrew Karolyi, and Rene Stulz, 2016, The U.S. Listing Gap, Journal of Financial Economics, forthcoming.

Duverger, Maurice, 1954, Political Parties: Their Organization and Activity in the Modern State, New York: Wiley.

Ferreira, Daniel, Gustavo Manso, and André Silva, 2014, Incentives to Innovate and the Decision to Go Public or Private, Review of Financial Studies 27, 256-300.

Floyd, Eric, Nan Li, and Douglas J. Skinner, 2015, Payout policy through the financial crisis: The growth of repurchases and the resilience of dividends, Journal of Financial Economics 118, 299-316.

Garicano, Luis, Claire LeLarge, and John Van Reenen, 2016, Firm Size Distortions and the Productivity Distribution: Evidence from France, American Economic Review 106, 3439-3479.

Gao, Xiaohui, Jay R. Ritter, and Zhongyan Zhu, 2013, Where Have All the IPOs Gone?, Journal of Financial and Quantitative Analysis 48, 1663-1692.

Greenwood, Jeremy, and Boyan Jovanovic, 1990, Financial Development, Growth, and the Distribution of Income, Journal of Political Economy 98, 1076-1107.

Grossman, Sanford, and Oliver Hart, 1980, Takeover Bids, the Free-Rider Problem, and the Theory of the Corporation, RAND Journal of Economics 11, 42-64.

Grossman, Sanford, and Joseph Stiglitz, 1980, On the Impossibility of Informationally Efficient Markets, American Economic Review 70, 393-408.

Harris, Richard, Donald S. Siegel, and Mike Wright, 2005, Assessing the Impact of Management Buyouts on Economic Efficiency: Plant-level Evidence from the United Kingdom, Review of Economics and Statistics 87, 148-153.

Hochberg, Yael, Alexander Ljungqvist, and Annette Vissing-Jørgensen, 2014, Informational Hold-up and Performance Persistence in Venture Capital, Review of Financial Studies 27, 102-152.

Holmstrom, Bengt, and Jean Tirole, 1993, Market Liquidity and Performance Monitoring, Journal of Political Economy 101, 678-709. 
Hsu, Hung-Chia, Adam V. Reed, and Jörg Rocholl, 2012, Competitive Effects of Private Equity Investments, Unpublished Working Paper.

Investment Company Institute, 2008, Equity Ownership in America, Washington, DC: Investment Company Institute.

Jensen, Michael, 1989, The Eclipse of the Public Corporation, Harvard Business Review (Sept.-Oct., revised 1997).

Kaplan, Steven, 1989, The Effects of Management Buyouts on Operating Performance and Value, Journal of Financial Economics 24, 217-254.

Kaplan, Steven, and Per Strömberg, 2009, Leveraged Buyouts and Private Equity, Journal of Economic Perspectives 23, 121-146.

Kaustia, Markku, Samuli Knüpfer, and Sami Torstila, 2016, Stock Ownership and Political Behavior: Evidence from Demutualizations, Management Science 62, 945-963.

Lee, David, and Alexandre Mas, 2012, Long-Run Impacts of Unions on Firms: New Evidence from Financial Markets, 1961-1999, Quarterly Journal of Economics 127, 333-378.

Lerner, Josh, Morten Sørensen, and Per Strömberg, 2011, Private Equity and Long-run Investment: The Case of Innovation, Journal of Finance 64, 445-477.

Levine, Ross, 1991, Stock Markets, Growth, and Tax Policy, Journal of Finance 46, 1445-65.

Lichtenberg, Frank R., and Donald Siegel, 1990, The Effects of Leveraged Buyouts on Productivity and Related Aspects of Firm Behavior, Journal of Financial Economics 27, 165-194.

Olsson, Martin, and Joacim Tåg, 2017, Private Equity, Layoffs, and Job Polarization, Journal of Labor Economics, forthcoming.

Ott, Julia Cathleen, 2004, The "Free and Open" "People's Market": Public Relations at the New York Stock Exchange, 1913-1929, Business and Economic History 2, 1-43.

Ott, Julia Cathleen, 2007, When Wall Street Met Main Street: The Quest for an Investors' Democracy and the Emergence of the Retail Investor in the United States, 1890-1930, Ph.D. Dissertation, Yale University. 
Ott, Julia Cathleen, 2008, When Wall Street Met Main Street: The Quest for an Investors' Democracy and the Emergence of the Retail Investor in the United States, 1890-1930, Enterprise and Society 9, 619-630.

Pagano, Marco, 1993, The Flotation of Companies and the Stock Market: A Coordination Failure Model, European Economic Review 37, 1101-1125.

Pagano, Marco, and Paolo Volpin, 2001, The Political Economy of Finance, Oxford Review of Economic Policy 17, 502-519.

Pagano, Marco, and Paolo Volpin, 2006, Shareholder Protection, Stock Market Development, and Politics, Journal of the European Economic Association 4, 315-341.

Palfrey, Thomas R., 1989, A Mathematical Proof of Duvergers Law, In: Peter C. Ordeshook (ed.), Models of Strategic Choice in Politics, Ann Arbor: University of Michigan Press.

Perotti, Enrico, and Ernst-Ludwig von Thadden, 2006, The Political Economy of Corporate Control and Labor Rents, Journal of Political Economy 114, 145-175.

Pew Research Center, 2012, Nonvoters: Who They Are, What They Think, Washington, DC: Pew Research Center. Available at www.people-press.org/files/legacy-pdf/11-1-12 Nonvoters Release.pdf.

Schmidt, Klaus, 2000, The Political Economy of Mass Privatization and the Risk of Expropriation, European Economic Review 44, 393-421.

Scharfstein, David, 1988, The Disciplinary Role of Takeovers, Review of Economic Studies 55, 185-199.

Shearer, Ellen, 2012, Nonvoters in America. Ipsos Public Surveys, available at www.scribd.com/ doc/116750837/SummaryReport-12-13-12.

Shleifer, Andrei, and Lawrence H. Summers, 1988, Breach of Trust in Hostile Takeovers, In: Alan J. Auerbach (ed.), Corporate Takeovers: Causes and Consequences, Chicago: University of Chicago Press.

Stein, Jeremy, 1988, Takeover Threats and Managerial Myopia, Journal of Political Economy 96, 61-80.

Survey of Consumer Finances, 2013, 2013 SCF Chartbook, Washington, DC: Board of Governors of the Federal Reserve System. Available at http://www.federalreserve.gov/econresdata/ scf/files/BulletinCharts.pdf. 
Van Reenen, John, 1996, The Creation and Capture of Rents: Wages and Innovation in a Panel of U.K.

Companies, Quarterly Journal of Economics 111, 195-226. 


\section{Appendix}

\section{A Proofs}

\section{A.1 Proof of Lemma 1}

Lemma 1 follows from $\frac{d k}{d \alpha}=-\frac{g^{\prime}\left(k^{*}\right)}{\alpha g^{\prime \prime}\left(k^{*}\right)-c^{\prime \prime}\left(k^{*}\right)}>0$ and from $\frac{d \pi}{d \alpha}=g\left(k^{*}\right)+\left(\alpha g^{\prime}\left(k^{*}\right)-c^{\prime}\left(k^{*}\right)\right) \frac{d k}{d \alpha}>0$, where $\alpha g^{\prime}\left(k^{*}\right)-c^{\prime}\left(k^{*}\right)=0$ from the first-order condition.

\section{A.2 Proof of Lemma 2}

A left-wing government sets $\alpha$ such that $\max _{\alpha} U_{w}\left(\alpha, k^{*}(\alpha)\right)$ with $\alpha \in[0,1]$. The optimal $\alpha_{l}^{*}$ is either one of the corner solutions (i.e., zero or one) or it is determined implicitly by the first-order condition:

$$
\frac{n+s}{\mu_{m}+\mu_{w}}\left[-g\left(k^{*}\right)+(1-\alpha) g^{\prime}\left(k^{*}\right) \frac{d k}{d \alpha}\right]=0,
$$

where $g^{\prime}\left(k^{*}\right) \frac{d k}{d \alpha}>0$ from Lemma 1 and where we assume that the second-order condition holds such that we obtain an interior solution. ${ }^{30}$ A right-wing government sets $\alpha \in[0,1]$ such that $\max _{\alpha} U_{r}\left(\alpha, k^{*}(\alpha)\right)$. We now proceed to show by contradiction that the optimal $\alpha$ cannot be an interior solution. Suppose the solution is interior. The optimal $\alpha_{r}^{*}$ is then given by the first-order condition:

$$
\frac{n}{\mu_{e}} \frac{d \pi}{d \alpha}=0
$$

However, this first order-condition can never hold, since $\frac{n}{\mu_{e}} \frac{d \pi}{d \alpha}>0$. This term is always positive since $\frac{d \pi}{d \alpha}=$ $g(k)+\frac{\partial \pi}{\partial k} \frac{d k}{d \alpha}=g(k)>0$ from the first-order condition for investment in Lemma 1. Thus, one of the corner solutions has to be the optimal one. It is immediate that setting $\alpha_{r}=0$ cannot be optimal because then all gross profits are paid out in wages. Thus, the right-wing government always sets $\alpha_{r}=1$. It thus follows that a right-wing government sets a more business-friendly policy than a left-wing government does: $\alpha_{r}^{*}=1>\alpha_{l}^{*}$. From Lemma 1, investment is lower under a left-wing government. Comparing wages and net profits under a left-wing and a right-wing government, we have $\Delta_{w}^{*}=w\left(\alpha_{l}^{*}, k^{*}\left(\alpha_{l}^{*}\right)\right)-w\left(\alpha_{r}^{*}, k^{*}\left(\alpha_{r}^{*}\right)>0\right.$ since $w\left(\alpha, k^{*}(\alpha)\right)$

\footnotetext{
${ }^{30}$ The second-order condition is given by $\frac{(1-\alpha) g^{\prime}(k) g^{\prime}(k) g^{\prime \prime}(k)}{\left[\alpha g^{\prime \prime}(k)-c^{\prime \prime}(k)\right]^{2}}+\frac{g^{\prime}(k) g^{\prime}(k)}{\alpha g^{\prime \prime}(k)-c^{\prime \prime}(k)}-g^{\prime}(k) \frac{d k}{d \alpha}-\frac{2(1-\alpha) g^{\prime}(k) g^{\prime \prime}(k)}{\alpha g^{\prime \prime}(k)-c^{\prime \prime}(k)} \frac{d k}{d \alpha}+$ $\frac{(1-\alpha) g^{\prime}(k) g^{\prime}(k)\left[\alpha g^{\prime \prime \prime}(k)-c^{\prime \prime \prime}(k)\right]}{\left[\alpha g^{\prime \prime}(k)-c^{\prime \prime}(k)\right]^{2}} \frac{d k}{d \alpha}<0$. We show in the existence proof that follows later in the appendix that if $g(k)$ is linear and $c(k)$ quadratic in $k$, then the second-order condition always holds.
} 
is maximized at $\alpha_{l}^{*}$ and $\Delta_{\pi}^{*}=\pi\left(\alpha_{l}^{*}, k^{*}\left(\alpha_{l}^{*}\right)\right)-\pi\left(\alpha_{r}^{*}, k^{*}\left(\alpha_{r}^{*}\right)\right)<0$ since $\frac{d \pi}{d \alpha}=g(k)+\left(\alpha g^{\prime}\left(k^{*}\right)-c^{\prime}\left(k^{*}\right)\right) \frac{d k}{d \alpha}>0$ where $\alpha g^{\prime}\left(k^{*}\right)-c^{\prime}\left(k^{*}\right)=0$ from the first-order condition, and $\alpha_{l}^{*}<\alpha_{r}^{*}$.

\section{A.3 Proof of Proposition 1}

To get delistings to affect the election outcome, we need Conditions 1 and 2 to hold simultaneously. To see that Conditions 1 and 2 can hold simultaneously, note that Condition 1 holds if $q$ is sufficiently close to 1 since $\Delta_{w}^{*}$ and $\Delta_{\pi}^{*}$ are independent of $q$. Intuitively, we can always make the middle class vote left if we delist all firms. Similarly, suppose that $q=1, n=s, \mu_{m}=1$, and $\mu_{w}=1$. Then the middle class always votes right since $\Delta_{w}^{*}+\Delta_{\pi}^{*}<0$. The negative effect on net profits strictly outweighs the positive effect on wages since gross profits net of capital expenditures, $g(k)-c(k)$, which are to be split between wages and capital income paid to shareholders, will fall as investment drops from $k^{*}\left(\alpha_{r}\right)$ to $k^{*}\left(\alpha_{l}\right)$. Condition 2 holds if $-\left(b_{q}+t\right)$ is large enough, which occurs when $t$ is low and $b_{q}$ is sufficiently negative. Both conditions can thus hold at the same time since Condition 1 is unaffected by $b_{q}$ and $t$. Note also that for $q$ to make both conditions more likely to hold, we must have $-\left(b_{q}+t\right)>0$. This condition simply says that the profit per firm that delists has to be sufficiently high to ensure that delistings are privately optimal.

To see formally that a reduction in the number of listed firms, holding constant the total number of firms in the economy, can either make delistings more or less likely to change the election outcome, consider first Condition 1. If we keep the total number of firms, $N=s+n$, constant and change $s$, the terms $\frac{n+s}{\mu_{m}+\mu_{w}}, \Delta_{w}^{*}$, and $\Delta_{\pi}^{*}$ will remain unchanged since the equilibrium policies $\alpha_{r}^{*}$ and $\alpha_{l}^{*}$ remain unchanged. The left-hand side of Condition 1 is then more likely to hold as $s$ decreases. The right-hand side of the condition is less likely to hold, which is why we need the condition that it remains negative $\left(\frac{n+s}{\mu_{m}+\mu_{w}} \Delta_{w}^{*}+\frac{s}{\mu_{m}} \Delta_{\pi}^{*} \leq 0\right)$. Consider now Condition 2. The first term remains unchanged, but the second and third terms change. On the one hand, a larger number of listed firms makes middle-class citizens less willing to sell out to the PE investor since they will remain shareholders in the $(1-q) s$ firms that do not delist. (This effect is captured by the term $\frac{1-q}{\mu_{m}} \Delta_{\pi}^{*}$.) On the other hand, more listed firms means that potentially more firms can delist, so there are more

benefits for the middle class to earn from delistings. (This effect is captured by the term $\frac{q}{\mu_{m}}\left(\Delta_{\pi}-b_{q}-t\right)$.) If the latter effect dominates the former, a smaller number of listed firms ( $s$ low) will make it more likely that delistings change the election outcome. 


\section{A.4 Proof of Proposition 3}

Note first that excessive delistings can only occur when they change the election outcome. To see this, consider the case when they do not change the election outcome (i.e., when Condition 1 does not hold). The private incentives to delist firms are determined as follows. From Lemma 3, independently of delistings the left-wing party will always win the election if $\frac{n+s}{\mu_{m}+\mu_{w}} \Delta_{w}^{*}+\frac{s}{\mu_{m}} \Delta_{\pi}^{*} \geq 0$. In this case, the PE investor is willing to delist the $q s$ firms if $p \leq \pi_{l}^{*}-t$, and a middle-class citizen is willing to sell her shares if $p \geq \pi_{l}^{*}+b_{q}$. They can thus agree on delisting the firms when $-b_{q}-t>0$ (i.e., when the net benefits of being listed for the $q s$ firms are negative enough to compensate for the costs of taking them private). From Lemma 3 , independently of delistings the right-wing party will always win the election if $\frac{n+s}{\mu_{m}+\mu_{w}} \Delta_{w}^{*}+\frac{(1-q) s}{\mu_{m}} \Delta_{\pi}^{*}<0$. In that case, the PE investor is willing to delist the $q s$ firms if $p \leq \pi_{r}^{*}-t$, and a middle-class citizen is willing to sell her shares if $p \geq \pi_{r}^{*}+b_{q}$. Again, they can agree on delisting the firms when $-\left(b_{q}+t\right)>0$.

The social incentives to delist firms are determined as follows. From equation (11), it follows that it is socially optimal to delist firms whenever $-\left(b_{q}+t\right)>0$. Since this condition always coincides with the condition for privately optimal delistings, there is no conflict between private and social incentives to delist firms when delistings do not change the election outcome.

To see part (i), note that Condition 3 always holds when $-\left(b_{q}+t\right)$ is large but fails to hold when $-\left(b_{q}+t\right)$ is small. Condition 2, however, requires $-\left(b_{q}+t\right)$ to be large; otherwise, delistings would not be privately optimal and so would not take place. Thus, the private and social incentives to delisting can only diverge when the cost savings are in an intermediate range: large enough to be privately profitable and small enough not to be socially optimal.

To see part (ii), note that Condition 3 is independent of $\frac{\mu_{m}}{\mu_{m}+\mu_{w}}$ while Condition 2 is more likely to hold as $\frac{\mu_{m}}{\mu_{m}+\mu_{w}}$ increases. Thus, as $\frac{\mu_{m}}{\mu_{m}+\mu_{w}}$ increases, delistings are more likely to be privately optimal but less likely to be socially optimal.

To see part (iii), note that the negative externality on entrepreneurs' incomes is larger the fewer listed firms $(s)$ and the more privately held firms $(n)$ there are. As a result, Condition 3 for when delistings are socially desirable is less likely to hold as $s$ decreases and $n$ increases. At the same time, from Proposition 1 , Condition 2 for when delistings are privately desirable is more likely to hold as $s$ decreases and $n$ increases as long as $\frac{n+s}{\mu_{m}+\mu_{w}} \Delta_{w}^{*}+\frac{s}{\mu_{m}} \Delta_{\pi}^{*} \leq 0$ and $\frac{1-q}{\mu_{m}} \Delta_{\pi}^{*}+\frac{q}{\mu_{m}}\left(\Delta_{\pi}-b_{q}-t\right)>0$. This implies that a reduction in $s$ has opposite effects on the private and social incentives for delistings. 


\section{A.5 Proof of Proposition 4}

We next show how the private and social incentives to delist firms change when the PE investor manages pension assets and shares the gains from delistings with all citizens in the economy. This leaves the investment stage unchanged. The business policy stage changes as entrepreneurs and workers now account for their pension holdings when delistings take place.

As before, a left-wing government is less business-friendly than a right-wing government: $0<\alpha_{w}^{*}<$ $\alpha_{r}^{*}=1$, where $\alpha_{w}^{*}$ now denotes the business policy of the left-wing government when workers have pension holdings. The left-wing government is now more business friendly than in the baseline model, $\alpha_{w}^{*}>\alpha_{l}^{*}$, as workers in this extension also derive utility from corporate profits through their pensions. This affects the change in wages and profits as we go from a right-wing to a left-wing government. Denote these changes by $\Delta_{w p}^{*}$ and $\Delta_{\pi p}^{*}$. When no delistings take place, the utility functions and the resulting business policy choices are as in the baseline model.

As each citizen votes for the party that maximizes her utility, entrepreneurs vote for the right-wing party and workers vote for the left-wing party. A middle-class citizen's utility depends on whether delistings have taken place. Note that the PE investor's profit is zero in the absence of delistings. We have:

$$
U_{m}= \begin{cases}\frac{n+s}{\mu_{m}+\mu_{w}} w+\frac{(1-q) s}{\mu_{m}}\left(\pi+b_{1-q}\right)+\frac{q s}{\mu_{m}} p+\frac{1}{\mu}(1-f) q s(\pi-t-p) & \text { with delistings, } \\ \frac{n+s}{\mu_{m}+\mu_{w}} w+\frac{(1-q) s}{\mu_{m}}\left(\pi+b_{1-q}\right)+\frac{q s}{\mu_{m}}\left(\pi+b_{q}\right) & \text { without delistings. }\end{cases}
$$

A middle-class citizen votes left if $U_{m}($ left $) \geq U_{m}$ (right). This means that if delistings have taken place, a middle-class citizen votes left if:

$$
\frac{n+s}{\mu_{m}+\mu_{w}} \Delta_{w p}^{*}+\frac{(1-q) s}{\mu_{m}} \Delta_{\pi p}^{*}+\frac{1}{\mu}(1-f) q s \Delta_{\pi p}^{*} \geq 0
$$

There are two differences in this expression relative to the baseline model. First, the left-wing government is now more business friendly since workers care about the gains from delistings and thus about corporate profits. This means that the changes in wages and profits are smaller relative to the baseline case. If the fee the PE investor charges for managing pension assets, $f$, equals one, the PE investor captures all the gains from delistings and we are back in the baseline model. Second, middle-class citizens place a greater weight on corporate profits since they share in the PE investor's gains from delistings (the final term in the 
expression above). This makes them more likely to vote right but decreasingly so as $f$ falls. If no delistings have taken place, a middle-class citizen votes left if $\frac{n+s}{\mu_{m}+\mu_{w}} \Delta_{w}^{*}+\frac{s}{\mu_{m}} \Delta_{\pi}^{*} \geq 0$

Now consider the delisting stage, where the PE investor has the opportunity to buy $q s$ firms at a price $p$ per firm. A change in the election outcome from right to left will take place when the following condition holds:

$$
\frac{n+s}{\mu_{m}+\mu_{w}} \Delta_{w p}^{*}+\frac{(1-q) s}{\mu_{m}} \Delta_{\pi p}^{*}+\frac{1}{\mu}(1-f) q s \Delta_{\pi p}^{*} \geq 0>\frac{n+s}{\mu_{m}+\mu_{w}} \Delta_{w}^{*}+\frac{s}{\mu_{m}} \Delta_{\pi}^{*}
$$

This condition corresponds to Condition 1 in the baseline model. Suppose that it holds. The PE investor's utility under business policy $\alpha$ when taking $q s$ firms private at a transaction cost $t$ per firm is then given by:

$$
U_{p e}(\alpha, q)=q s f\left(\pi\left(\alpha, k^{*}(\alpha)\right)-t-p\right)
$$

For each delisted firm, the PE investor obtains the stipulated share of the gains, net of transaction costs $t$ and having paid the price $p$. Knowing that delistings shift business policy, the PE investor is willing to buy all shares of the $q s$ firms at price $p_{p e}$ such that $p_{p e} \leq \pi_{l}^{*}-t$. The PE investor's utility increases in the fee for managing pension assets and in the delisted firms' net profits under a left-wing government, and it decreases in the transaction cost $t$.

Each middle-class citizen has a reservation price $p_{m}$, such that

$$
\begin{aligned}
& \underbrace{\frac{n+s}{\mu_{m}+\mu_{w}} w_{l}^{*}+\frac{(1-q) s}{\mu_{m}}\left(\pi_{l}^{*}+b_{1-q}\right)+\frac{q s}{\mu_{m}} p_{m}+\frac{1}{\mu}(1-f) q s\left(\pi_{l}^{*}-t-p_{m}\right)}_{\text {Sell shares, left-wing party wins }} \geq \\
& \underbrace{\frac{n+s}{\mu_{m}+\mu_{w}} w_{r}^{*}+\frac{(1-q) s}{\mu_{m}}\left(\pi_{r}^{*}+b_{1-q}\right)+\frac{q s}{\mu_{m}}\left(\pi_{r}^{*}+b_{q}\right)}_{\text {Do not sell shares, right-wing party wins }} .
\end{aligned}
$$

Note that when setting their reservation price, the middle-class citizens now account for the gains from delistings since they share in them. Solving for $p_{m}$, we obtain

$$
p_{m} \geq\left[\frac{q s}{\mu_{m}}-\frac{(1-f) q s}{\mu}\right]^{-1}\left[\frac{q s}{\mu_{m}}\left[\pi_{r}^{*}+b_{q}\right]-\frac{(1-f)}{\mu} q s\left[\pi_{l}^{*}-t\right]-\frac{n+s}{\mu_{m}+\mu_{w}} \Delta_{w}^{*}-\frac{(1-q) s}{\mu_{m}} \Delta_{\pi}^{*}\right] .
$$

By relating $p_{p e}$ to $p_{m}$, we obtain the modified Condition 2 for when delistings are privately optimal:

$$
\pi_{l}^{*}-t-\left[\frac{q s}{\mu_{m}}-\frac{(1-f) q s}{\mu}\right]^{-1}\left[\frac{q s}{\mu_{m}}\left[\pi_{r}^{*}+b_{q}\right]-\frac{(1-f)}{\mu} q s\left[\pi_{l}^{*}-t\right]-\frac{n+s}{\mu_{m}+\mu_{w}} \Delta_{w}^{*}-\frac{(1-q) s}{\mu_{m}} \Delta_{\pi}^{*}\right] \geq 0 .
$$


Although quite involved, it collapses to the standard Condition 2 when the PE investor captures all the gains from delistings $(f=1)$.

We have now obtained the modified versions of Condition 1 (for when delistings change the election outcome) and Condition 2 (for when delistings are privately optimal). Since pensions simply increase by an amount equal to citizens' share of the gains from delistings, it is immediate that Condition 3 (for when delistings are socially optimal) becomes

$$
(n+s)\left(\Delta_{w p}^{*}+\Delta_{\pi p}^{*}\right)-q s\left(b_{q}+t\right) \geq 0 .
$$

We can decompose this condition into equation (21) which is equation (14) updated to reflect pension holdings. From this expression, we can see that excessive delistings in the presence of a PE investor who manages pension assets occur when the sum of the first and the last terms is negative and when the middle term is weakly positive.

\section{A.6 Proof of Proposition 5}

We focus on the $\mu_{m q}$ middle-class citizens since they determine the election outcome by assumption. With delistings, the utility of a middle-class citizen of this type is $\frac{n+s}{\mu_{m}+\mu_{w}} w+\frac{q s}{\mu_{m q}} p$, given that ownership of the $q s$ delisting firms is split equally among the $\mu_{m q}$ citizens who sell. Without delistings, their utility is $\frac{n+s}{\mu_{m}+\mu_{w}} w+$ $\frac{q s}{\mu_{m q}}\left(\pi+b_{q}\right)$.

The investment stage and the business policy stage are unaffected. Consider now the election stage and assume delistings take place. In this case, a citizen of type $\mu_{m q}$ votes left if

$$
\begin{aligned}
\frac{n+s}{\mu_{m}+\mu_{w}} w_{l}^{*}+\frac{q s}{\mu_{m q}} p-\left[\frac{n+s}{\mu_{m}+\mu_{w}} w_{r}^{*}+\frac{q s}{\mu_{m q}} p\right] & \geq 0 \\
\frac{n+s}{\mu_{m}+\mu_{w}} \Delta_{w}^{*} & \geq 0 .
\end{aligned}
$$

Since $\Delta w^{*}>0$, the left-wing party wins the election if delistings take place. We next solve for the conditions under which delistings take place. As before, there will be a shift from right to left if delistings affect the election outcome. Thus, Condition 1 now becomes:

$$
\frac{n+s}{\mu_{m}+\mu_{w}} \Delta_{w}^{*} \geq 0>\frac{n+s}{\mu_{m}+\mu_{w}} \Delta_{w}^{*}+\frac{q s}{\mu_{m q}} \Delta \pi^{*}
$$


The PE investor's reservation price, $p_{p e}$, remains unchanged so that we have $p_{p e} \leq \pi_{l}^{*}-t$. The reservation price of a middle-class citizen of type $\mu_{m q}, p_{m q}$, can be derived by comparing the utility of delisting the firms and having the left-wing party win the election to the utility of not delisting the firms and leaving the right-wing party in power. We get:

$$
p_{m q} \geq \pi_{r}^{*}+b_{q}-\frac{\mu_{m q}}{q s} \frac{n+s}{\mu_{m}+\mu_{w}} \Delta_{w}^{*}
$$

We can now derive the condition that must hold for delistings to take place (Condition 2). The PE investor is willing to buy all shares in the $q s$ firms if $p_{p e} \geq p_{m q}$, i.e., if

$$
\Delta \pi^{*}-t-b_{q}+\frac{\mu_{m q}}{q s} \frac{n+s}{\mu_{m}+\mu_{w}} \Delta_{w}^{*} \geq 0
$$

We next examine how each group is affected by delistings that change the election outcome from right to left. The effects on entrepreneurs and on workers are unchanged. The transaction involves the $\mu_{m q}$ middle-class citizens and the PE investor, whose aggregate surplus is:

$$
\mu_{m q} \frac{n+s}{\mu_{m}+\mu_{w}} \Delta w^{*}+q s\left(\Delta \pi^{*}-b_{q}-t\right) .
$$

The first term is positive since $\Delta w^{*}>0$. The second term is either positive or equal to zero. This follows from the condition that must hold for delistings to take place in the first place. Thus, middle-class citizens of type $\mu_{m q}$ weakly benefit from delistings. By contrast, the remaining middle-class citizens, $\mu_{m(1-q)}$, only benefit from delistings if

$$
\mu_{m(1-q)}\left[\frac{n+s}{\mu_{m}+\mu_{w}} \Delta w^{*}+\frac{(1-q) s}{\mu_{m(1-q)}} \Delta \pi^{*}\right]>0 .
$$

Intuitively, these middle-class citizens lose out because they receive less capital income when delistings take place. However, they also benefit through higher wages. If the effect on their utility from the wage increase is smaller than the loss in capital income from a change in business policy, they will lose out when delistings take place. 


\section{A.7 Existence}

This subsection shows that there exists at least one set of functions and parameter values that fulfill the conditions stated in the lemmas and propositions of the model. To proceed, assume that the gross profit function is $g(k)=k$ and that investment costs are quadratic, such that $c(k)=\frac{1}{2} k^{2}$ with $k$ strictly positive. We have $g^{\prime}(k)=1, g^{\prime \prime}(k)=0, c^{\prime}(k)=k$, and $c^{\prime \prime}(k)=1$. Also suppose that $\mu_{m}=1$. We next restate the lemmas, conditions, and propositions of the general model for the case of this specific gross profit function.

Lemma 1. Optimal investment $k^{*}=\alpha$ is given by the first-order condition $\alpha-k=0$. The second-order condition relating to the optimal investment condition is fulfilled since $\alpha g^{\prime \prime}(k)-c^{\prime \prime}(k)=-1<0$. Investment increases in how business-friendly the government's policy is: $\frac{d k}{d \alpha}=\frac{-1}{-1}=1>0$.

Lemma 2: A left-wing government is less business-friendly than a right-wing government: $0<\alpha_{l}^{*}=$ $\frac{1}{2}<\alpha_{r}^{*}=1$. The first-order condition for $\alpha_{l}^{*}$ is $1-2 \alpha=0$ and the second-order condition, $-2<0$, is fulfilled. As a result, an election win for the left-wing party leads to higher wages but lower investment and lower net profits in the economy: $\Delta_{w}^{*}=w_{l}^{*}-w_{r}^{*}=\frac{1}{4}>0, k_{l}^{*}=\frac{1}{2}<1=k_{r}^{*}$, and $\Delta_{\pi}^{*}=\pi_{l}^{*}-\pi_{r}^{*}=-\frac{3}{8}<0$. Also note that $\Delta_{w}^{*}+\Delta_{\pi}^{*}=-\frac{1}{8}<0$.

Lemma 3. If delistings take place, a middle-class citizen votes for the left-wing party if $\frac{(n+s)}{1+\mu_{w}} \frac{1}{4}-\frac{3}{8}(1-$ $q) s \geq 0$, and otherwise for the right-wing party.

\section{Condition 1.}

$$
\frac{(n+s)}{1+\mu_{w}} \frac{1}{4}-\frac{3}{8}(1-q) s \geq 0>\frac{(n+s)}{1+\mu_{w}} \frac{1}{4}-\frac{3}{8} s
$$

Condition 2.

$$
\frac{(n+s)}{1+\mu_{w}} \frac{1}{4}-\frac{3}{8} s+q s\left(-b_{q}-t\right) \geq 0 .
$$

\section{Condition 3.}

$$
(n+s)\left(\frac{1}{4}-\frac{3}{8}\right)+q s\left(-b_{q}-t\right) \geq 0 .
$$

Proposition 2. Allocative effects. We have

$$
\underbrace{-\mu_{e} \frac{n}{\mu_{e}} \frac{3}{8}}_{\text {Entrepreneurs }}+\underbrace{\frac{(n+s)}{1+\mu_{w}} \frac{1}{4}-\frac{3}{8} s+q s\left(-b_{q}-t\right) \geq 0}_{\text {The middle class and the PE investor }}+\underbrace{\mu_{w} \frac{(n+s)}{1+\mu_{w}} \frac{1}{4}}_{\text {Workers }} \geq 0
$$

Thus, delistings will hurt entrepreneurs, weakly benefit the PE investor and the middle class, and benefit workers. 
Proposition 3. Welfare effects. For an example of excessive delistings, take $t=0, b_{q}=-1, s=4, n=5$, $\frac{1}{1+\mu_{w}}=\frac{3}{5}$, and $q=\frac{1}{5}$. Conditions $1\left(\frac{3}{20} \geq 0>-\frac{3}{20}\right)$ and $2\left(\frac{13}{20} \geq 0\right)$ are then fulfilled, but not Condition 3 $\left(-\frac{13}{40} \geq 0\right)$. 